\title{
Mechanisms underlying the tissue-specific and regulated activity of the Gnrhr promoter in mammals
}

\section{Anne-Laure Schang, Bruno Quérat, Violaine Simon, Ghislaine Garrel, Christian Bleux, Raymond Counis, Joëlle Cohen-Tannoudji and Jean-Noël Laverrière*}

Physiologie de l'Axe Gonadotrope, Biologie Fonctionnelle et Adaptative, EAC CNRS 4413, Sorbonne Paris Cité, Université Paris Diderot-Paris 7, Paris, France

\section{Edited by:}

Hubert Vaudry, University of Rouen, France

\section{Reviewed by:}

Jae Young Seong, Korea University, South Korea

Ursula B. Kaiser, Brigham and

Women's Hospital, USA

*Correspondence:

Jean-Noël Laverrière, Physiologie de I'Axe Gonadotrope, Biologie

Fonctionnelle et Adaptative, EAC CNRS 4413, Sorbonne Paris Cité, Université Paris Diderot-Paris 7, Bâtiment Buffon, case courrier 7007, 4 rue MA Lagroua Weill-Hallé, 75205 Paris Cedex 13, France. e-mail: jean-noel.laverriere@univ-parisdiderot.fr
The $\mathrm{GnRH}$ receptor (GnRHR) plays a central role in the development and maintenance of reproductive function in mammals. Following stimulation by $\mathrm{GnRH}$ originating from the hypothalamus, GnRHR triggers multiple signaling events that ultimately stimulate the synthesis and the periodic release of the gonadotropins, luteinizing-stimulating hormone (LH) and follicle-stimulating hormones (FSH) which, in turn, regulate gonadal functions including steroidogenesis and gametogenesis. The concentration of GnRHR at the cell surface is essential for the amplitude and the specificity of gonadotrope responsiveness. The number of $\mathrm{GnRHR}$ is submitted to strong regulatory control during pituitary development, estrous cycle, pregnancy, lactation, or after gonadectomy. These modulations take place, at least in part, at the transcriptional level. To analyze this facet of the reproductive function, the $5^{\prime}$ regulatory sequences of the gene encoding the GnRHR have been isolated and characterized through in vitro and in vivo approaches. This review summarizes results obtained with the mouse, rat, human, and ovine promoters either by transient transfection assays or by means of transgenic mice.

Keywords: GnRH receptor, promoter regions, transcription, gonadotrope cell lines, steroidogenic factor 1, homeodomain proteins, transgenic mice

\section{INTRODUCTION}

Two GnRH systems (GnRH decapeptides and specific receptors) originally existed in the common mammalian ancestor but a large number of extant species have lost either the second type GnRH or its receptor (Stewart et al., 2009). Humans possess GnRH-II but lack a functional type-II receptor whereas mouse and rats lack both of them. In this paper, we will be dealing with the only GnRH system that has been proved to be involved in the reproductive hormonal cascade and that was retained in either humans or the two rodent models. The pituitary GnRH receptor (GnRHR) plays a central role in mammalian reproductive function since it establishes a unique molecular link between its ligand, the decapeptide GnRH originating from the hypothalamus, and the gonadotrope cells in the anterior pituitary. The hypothalamic $\mathrm{GnRH}$ is released into the portal hypophyseal vasculature in a periodic manner through a pulse generator that, likely by means of both gap junctions and voltage-gated calcium channels, coordinates the activity of individual neurons diffusely distributed in the hypothalamus (Vazquez-Martinez et al., 2001). Within the anterior pituitary, GnRH binds to specific high-affinity receptors present at the surface of the gonadotrope cells and induces increase in the synthesis and pulsatile release of the gonadotropins, luteinizing and follicle-stimulating hormones ( $\mathrm{LH}$ and FSH). The pituitary hormones, which are composed of a common $\alpha$ - and distinct $\beta$-subunits, then enter the systemic circulation and, via specific receptors, modulate gonadal functions including gametogenesis, steroidogenesis, and ovulation. The amplitude and frequency of GnRH pulses relayed by the GnRHR appear critical in the development of the reproductive function, in the onset of puberty and throughout the menstrual or estrous cycle.

\section{INTRACELLULAR SIGNALING AND GnRHR-MEDIATED EFFECTS}

The activation of GnRHR may trigger several intracellular signaling pathways in gonadotrope cells depending on the cellular context. Two mouse gonadotrope tumor-derived cell lines expressing the GnRHR, $\alpha \mathrm{T} 3-1$ and $\mathrm{L} \beta \mathrm{T} 2$ cell lines, have been used as homogenous cell models to study gonadotrope function (Windle, et al., 1990; Alarid et al., 1996; Thomas et al., 1996; Turgeon et al., 1996). In both cell lines, GnRH activates the protein kinase C (PKC)-dependent signaling pathway through coupling to G proteins of the Gq/G11 family (see review in Anderson, 1996). In primary culture of rat pituitary cells under sustained GnRH stimulation, a cAMP/PKA pathway is preferentially recruited (Garrel et al., 2010). In the gonadotrope-derived L $\beta$ T2 cell line, sustained stimulation of GnRHR activates the cAMP signaling pathway through PKC $\delta$ and $\varepsilon$ (Larivière et al., 2007). Also, in these cells, GnRHR signaling has been shown to further involve the three mitogen-activator protein kinases (MAPK) subfamilies (Liu et al., 2002). In non-gonadotrope cells like insect or rat lactosomatotrope cells stably transfected with GnRHR, the signaling mechanisms may involve the PKA pathway via Gs or Gi (Stanislaus et al., 1996; Delahaye et al., 1997; see review in Kraus et al., 2001). GnRHR activation generates several intracellular processes in the gonadotropes leading to enhanced transcription of the common $\alpha$ and specific LH and FSH $\beta$ subunit genes and secretion of these gonadotropins. Among these processes have been described activation of the neuronal nitric oxide 
synthase, induction of cfos expression, increase in the early growth response protein 1 , increase in mRNA for annexin 5 and activation of translation and phosphorylation of the pituitary adenylate cyclase activating polypeptide (PACAP) type 1 receptor (see review in Garrel et al., 1995, 1997, 1998; Lozach et al., 1998; Brown and McNeilly, 1999; Sosnowski et al., 2000; Bachir et al., 2001, 2003; Duan et al., 2002; Kawaminami et al., 2002; Liu etal., 2002; Larivière et al., 2008). A global profile of genes regulated by $\mathrm{GnRH}$ in the L $\beta \mathrm{T} 2$ gonadotrope cell line was established through microarray analysis showing that more than 200 genes are either up- or down-regulated after GnRH agonist treatment (Kakar etal., 2003). The amplitude of these events is strictly dependent on the number of GnRHR molecules at the surface of the pituitary gonadotropes that is itself dependent, at least in part, on the transcriptional level of GnRHR gene (Gnrhr).

\section{GENE STRUCTURE AND PATHOLOGIES ASSOCIATED WITH MUTATIONS AFFECTING THE HUMAN GENE}

The cloning of its encoding cDNA, firstly in the mouse and subsequently in other mammalian species, revealed that GnRHR is 325-328 amino acid long (327 in mouse and rat, 328 in human) and confirmed that this receptor belongs to the serpentine family of transmembrane $\mathrm{G}$ protein-coupled receptors (review in Norwitz et al., 1999a and references therein). The cDNA probes have subsequently been used to characterize the gene and its chromosomal localization in various mammalian species. Gnrhr is composed of three exons and two introns and is approximately 15-31 kb in size depending on the species (Figure 1). It is localized to chromosome 4q21.2 in human, chromosome 4, 5, 6 , or 8 in bovine, murine, ovine, and porcine species, respectively (Fan et al., 1994; Kaiser et al., 1994; Morrison et al., 1994; Kakar and Neill, 1995; Kottler et al., 1995; Leung et al., 1995; Montgomery etal., 1995; Connor et al., 1999; Jiang et al., 2001).
Cloning of the human GNRHR cDNA has led to the identification of mutations in the coding sequence that are associated with variable clinical features ranging from partial to complete hypogonadotropic hypogonadism (Achermann et al., 2001; de Roux and Milgrom, 2001). Two separate groups initially reported loss-offunction mutations in the GNRHR gene in patients with isolated hypogonadotropic hypogonadism (de Roux et al., 1997; Layman et al., 1998). A natural knockout of the human GNRHR resulting from aberrant splicing that eliminates exon 2 and creates a frame shift in the coding sequence was reported (Silveira et al., 2002). The woman affected by this homozygous mutation presented with primary amenorrhea, absence of gonadotropin pulsatility and did not respond to exogenous pulsatile or acute $\mathrm{GnRH}$ administration. To date, at least 20 additional mutations in GNRHR have been identified in patients with sporadic and familial isolated hypogonadotropic hypogonadism (Chevrier et al., 2011; Noel and Kaiser, 2011). These data again lay emphasis on the predominant role of GNRHR in the development of reproductive function in humans.

\section{TISSUE- AND CELL-SPECIFIC EXPRESSION OF THE GnRHR}

The isolation of the cDNA also provided the basic tools for initiating studies on the regulation of Gnrhr expression by in situ hybridization, northern blotting, and semi quantitative RT-PCR. The presence of transcripts for the GnRHRs have notably been observed in brain regions previously shown to bind radiolabeled $\mathrm{GnRH}$, thus confirming that Gnrhr is expressed in non-pituitary tissues, notably in the hippocampus and hypothalamus (see review in Jennes et al., 1997). Gnrhr is also expressed in granulosa cells of atretic follicles in the ovary, in Leydig cells in the testis, in prostate, breast, and placenta (Stojilkovic et al., 1994). In the pituitary, the expression of Gnrhr is restricted to the gonadotrope cells despite the common origin of the six different secreting cell types that composed the anterior pituitary (Scully and Rosenfeld, 2002).

\section{Mouse gene Intron $11.8 \mathrm{~kb} \quad$ Intron $2.9 \mathrm{~kb}$ \\ Rat gene Intron $26.0 \mathrm{~kb} \quad$ Intron $2.8 \mathrm{~kb}$ \\ Human gene Intron $4.2 \mathrm{~kb}$ Intron $5.0 \mathrm{~kb}$}

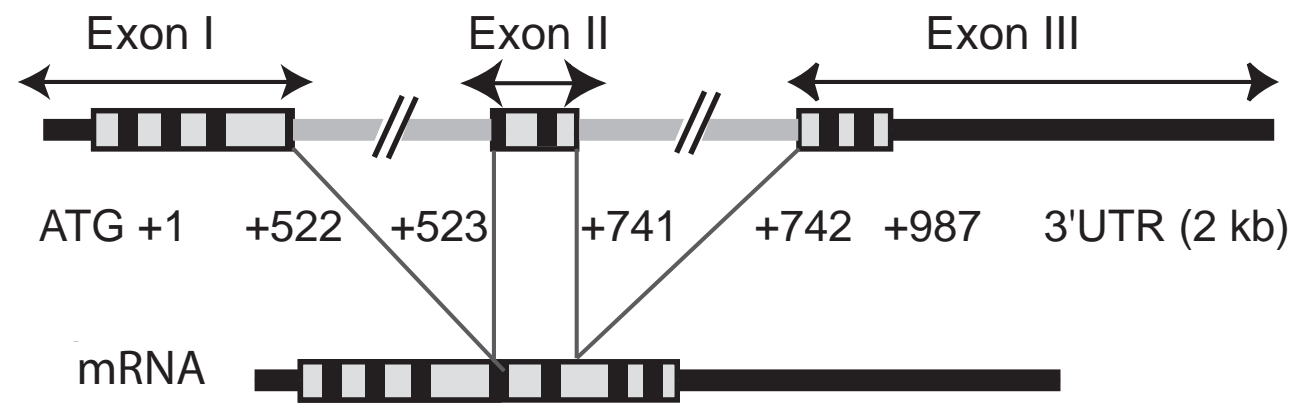

FIGURE 1 | Structure of the GnRH receptor gene. The GnRH receptor gene is $15-31 \mathrm{~kb}$ in size depending on the species. This is primarily due to differences in intron sizes which are indicated at the top of the figure for mouse, rat, and human species. The coding sequence is boxed with the trans-membrane domains specified in black. The $5^{\prime}$ and $3^{\prime}$ untranslated regions (UTR) are designated by thick black lines whereas the two introns are specified by thick gray lines. The mature mRNA resulting from usual intron splicing is illustrated below the gene. Sizes of translated sequences included in the human mature transcript are indicated (987 bp corresponding to 328 codons excluding the stop codon). Rat and mouse translated sequences are 327 amino acids long, the exon II being three bases shorter $(+523 /+738)$. 
These diverse and discrete sites of expression raise the question of the mechanisms that determine the tissue-specific expression of Gnrhr. In addition, Gnrhr is regulated by extracellular signals, the first of them being $\mathrm{GnRH}$ itself. Endocrine factors such as estradiol $\left(E_{2}\right)$, progesterone, or testosterone also regulate the levels of Gnrhr mRNA (Stojilkovic et al., 1994). Altogether, these data led several groups to investigate the mechanisms that underlie the tissue-specific expression and regulation of Gnrhr (see review in Hapgood et al., 2005).

To this aim, the $5^{\prime}$ regulatory sequences of the rat, mouse, and human receptor genes have been isolated and characterized essentially by transient transfection assays and gel-shift analyses. A limited number of studies have also been conducted in vivo through the elaboration of transgenic mouse lines harboring a reporter gene under the control of the mouse, rat, or ovine promoter. This review focuses on the present state of knowledge related to the cell-specific and regulated activity of the promoter of the Gnrhr in vitro and in vivo.

\section{IN VITRO ANALYSIS OF THE MOUSE, RAT, AND HUMAN PROMOTERS}

The tissue-specific and regulated activity of the rodent promoters have been evaluated using three main cellular models; the $\alpha \mathrm{T} 3-1$ and L $\beta$ T2 mouse gonadotrope-derived cell lines that are commonly used for studying the expression of marker genes of the gonadotrope lineage (Windle, et al., 1990; Alarid et al., 1996; Thomas et al., 1996; Turgeon et al., 1996) and a rat cell line of lactosomatotrope origin, the GGH(3) cells which were obtained by stable transfection with GnRHR of the tumor-derived GH3 cell line (Janovick et al., 1994; Kaiser et al., 1994; Stanislaus et al., 1994). aT3-1 cells express early marker genes of the developing gonadotrope in mouse, the gene encoding the common $\alpha$-subunit of the three pituitary glycoprotein hormones $(\mathrm{Cga})$ detected at embryonic day 11.5 (E11.5), Gnrhr detected at E13.5 and steroidogenic factor 1 ( $S f 1$, formally nuclear receptor subfamily 5, member 1, NR5A1) detected at E14.5. The L $\beta$ T2 cell line further expresses later marker genes, namely those encoding the $\beta$-subunits of $\mathrm{LH}(L h b)$, from E16.5 onward, and FSH $(F s h b)$, from E17.5. These data together with the way by which these cell lines were generated - by targeted oncogenesis using the promoter of $C g a$ and $L h b$, respectively - strongly suggest that the $\alpha$ T3-1 cell line may be representative of the gonadotrope lineage at early developmental stages, between E14 and E16.5. In contrast, the L $\beta$ T 2 cell line would be derived from cells at later stage, beyond E17.5 (Ingraham et al., 1994; Japón etal., 1994; Granger et al., 2004). It has to be emphasized that GGH3 cells express different tissue-specific transcription factors such as pituitary-specific transcription factor 1 (PIT1 formally POU domain class 1 transcription factor 1 , POU1F1) that directs the expression of $\mathrm{Prl}, \mathrm{Gh}$, and Tshb (Bodner et al., 1988; Ingraham et al., 1988; Li et al., 1990; Ngô et al., 1995). Also, gonadotrope and lactosomatotrope cells likely express ubiquitous transcription factors at different levels. Moreover, as already mentioned above, the GnRHR seems to be coupled to slightly different signal transduction pathways in these cell lines. Consequently, the results obtained with these cellular models may reflect these major differences.

\section{ELEMENTS INVOLVED IN THE GONADOTROPE-SPECIFIC ACTIVITY OF THE MOUSE AND RAT Gnrhr \\ The mouse promoter (Figure 2A)}

SF1, AP1, and GRAS elements. The $1.2 \mathrm{~kb}$ promoter of the mouse Gnrhr was the first to be isolated and characterized in 1994 by Albarracin et al. (1994) Shortly after, a 1.9 kb mouse promoter was further isolated and functionally characterized (Clay et al., 1995). Both studies allowed identification of multiple transcription start sites within the first $100 \mathrm{bp}$ immediately upstream from the ATG codon, the major one being located 62 nucleotides from the translation start codon. This transcription start site was referred to as position +1 in papers dealing with the mouse promoter. However, owing to the presence of multiple transcription start sites in GnRHR promoters and in order to facilitate the comparison between promoters of different species, we chose to use the translation start site as the position +1 in this review. Consequently, numbering in this review differs by +63 nucleotides from that currently used for the mouse promoter. This core promoter domain does not exhibit any typical CAAT or TATA boxes close to the transcription start sites. Both studies also demonstrated that the highest levels of promoter activity after transient transfection were obtained in mouse $\alpha \mathrm{T} 3-1$ gonadotrope-derived cells. In rat lactosomatotrope cell line (GH3) or human JEG-3 placental cells, the activity of the mouse promoter was considerably weaker and represented only 17 and 5\% of that observed in $\alpha$ T3-1 cells, respectively. Progressively, it appeared that all the positive regulatory elements involved in the tissue-specific activity of the mouse promoter in gonadotrope cells were confined into the 500 bp proximal region (Duval et al., 1997a,b). Three distinct motifs making up a tripartite basal enhancer are essentially required: a SF1 (NR5A1) response element $\left(-2435^{\prime}\right.$ TGGCCTTCA-3' -235$)$, a canonical activating protein 1 (AP1) motif ( $-3365^{\prime}$-TGAGTCA-3' -330$)$, and a novel element termed GnRHR activating sequence (GRAS; - 391 5' -CTAGTCACAACA$3^{\prime}-380$; Figure 2). Mutation of all three elements fully abrogates promoter activity. The identity of SF1 was further corroborated by gel-shift and antibody super-shift assays. Using similar approaches, the AP1 complex has been found to involve factors likely belonging to the FOS and JUN families. The nature of the factors that bind the GRAS element were also deciphered. They consist of SMAD3 (mothers against decapentaplegic homolog 3 ) which interacts with SMAD 4 and bind to the $5^{\prime}$ end of the GRAS motif, AP1 that binds within the middle of the motif, and FOXL2, a member of the forkhead family, that interacts with the $3^{\prime}$ end of the GRAS motif. GRAS is thus a composite regulatory element whose functional activity is dependent on a multi-protein complex (Ellsworth et al., 2003a).

Homeobox transcription factors. Several homeobox factors further participate in the combinatorial code that directs gonadotrope-specific expression of the mouse Gnrhr promoter. The paired-like homeodomain transcription factor 1 (PITX1) belongs to the expanding family of bicoid-related vertebrate homeobox genes. It appears very early, being involved in the specification of the adenohypophyseal placode and its expression in the anterior pituitary persists afterward until adulthood (Drouin et al., 1998; Schlosser, 2006). PITX1 regulates different marker genes in 


\section{A - Mouse promoter}

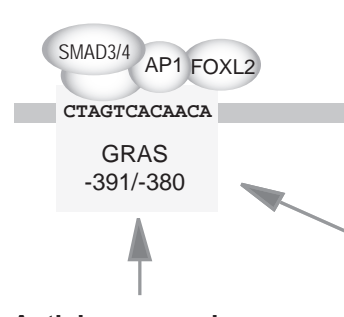

Activin responsiveness
Major transcription start site (-62)

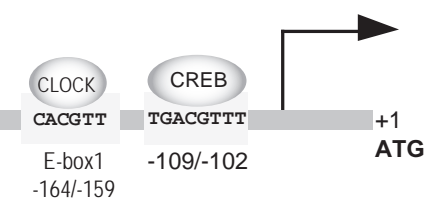

\section{B - Rat promoter}

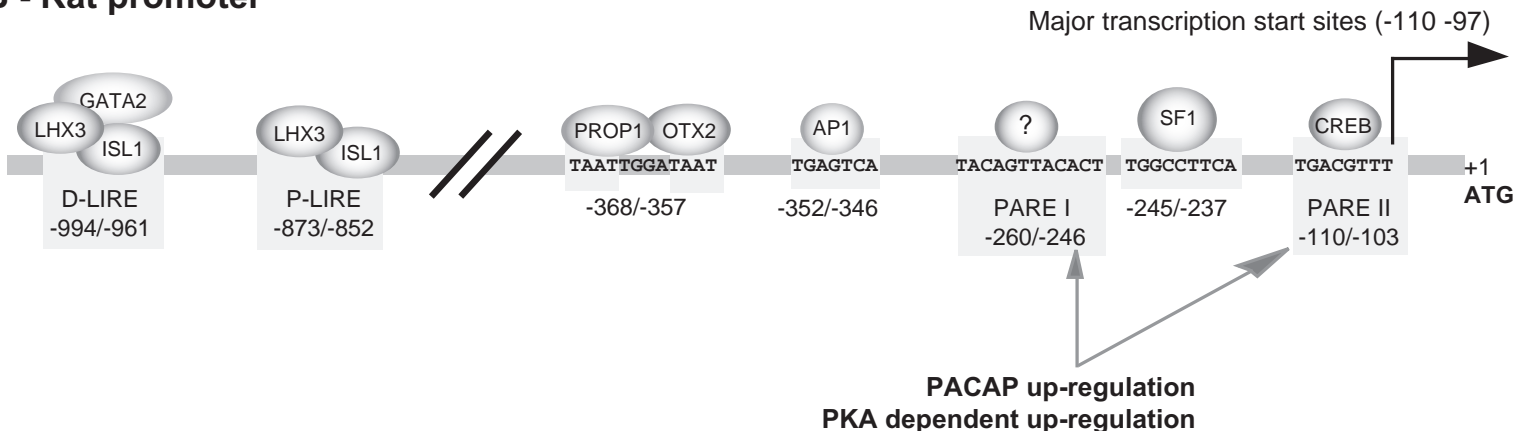

FIGURE 2 | Response elements identified within the mouse and rat promoters. The schema summarizes the functional elements characterized on mouse $(\mathbf{A})$ and rat $(\mathbf{B})$ promoters. These elements are involved in tissue-specific expression in gonadotrope cell lines, some of them being also involved in activin-, $\mathrm{GnRH}-$, and PACAP-dependent regulation. Note that response elements directing gonadotrope-specific expression of the rat promoter are located within $1000 \mathrm{bp} 5^{\prime}$ upstream of the ATG codon whereas those of the mouse promoter are confined within the most proximal $400 \mathrm{bp}$. The numbering is relative to the translation start codon, the adenine being considered at position +1 . This numbering may therefore be different from that used in the original publications. the adult pituitary notably $C g a, L h b, F s h b, T s h b, G h, P r l, P o m c$, and Gnrhr (Drouin et al., 1998). PITX1 activates the Gnrhr promoter by interacting with c-JUN in the AP1 complex and by binding to several low affinity response elements scattered within the $-370 /-326$ region of the mouse promoter that includes the AP1 response element (Jeong et al., 2004). Octamer-binding transcription factor 1 (OCT1, formally POU2F1) belongs to the other members of homeodomain transcription factors that regulate the Gnrhr promoter activity. This was demonstrated by several convergent approaches including targeted mutagenesis coupled with gel-shift assays and transient transfection in gonadotrope cell lines, chromatin immunoprecipitation (ChIP) assay, and short interfering RNA strategy (Kam et al., 2005). Together with the discovery of the OCT1 response element that contains a core TAAT motif at position $-352 /-349$, a functional binding site for nuclear factor $Y$ (NFY) was identified in the course of this study. It partially overlaps the OCT1 response element. Both transcription factors contribute to the tissue-specific activity of the mouse Gnrhr promoter. Several other TAAT motifs are present in the sequence of the mouse promoter. One of them, located at position $-164 /-159$, mediates OCT1 trans-acting stimulation of Gnrhr promoter in addition to the distal OCT1 interacting motif (Lents et al., 2009). Additional homeodomain factors are involved in promoter activity. LHX3 that belongs to the LIM homeodomain (LIM-HD) proteins is expressed in the early stages of pituitary ontogenesis at E9.5 and its expression persists in the adulthood (Ericson et al., 1998). Similarly to PITX1, LHX3 is involved in the expression of several pituitary marker genes. An ATTA motif located at -360/-357 was found to mediate the mouse Gnrhr promoter responsiveness to LHX3. Also, the presence of LHX3 on the mouse promoter was demonstrated in vivo by ChIP assay (McGillivray et al., 2005). A complementary study showed that responsiveness to LHX3 was further dependent on a second TAAT motif located only 4 bp downstream (Cherrington et al., 2006). The integrity as well as the specific helical orientation of the two motifs are required for full LHX3 activity.

E-box transcription factors. Seven non-canonical E-boxes have been identified along the Gnrhr promoter sequence suggesting that basic/helix-loop-helix (b/HLH) transcription factors might be involved in tissue-specific promoter activity. b/HLH transcription factors (124 in numbers in mouse) have been classified into six groups based on their evolutionary relationship, protein structure characteristics, and sequence binding affinities (Li et al., 2006). Four of them, belonging to class A, B, and C, are suspected to modulate the activity of the mouse Gnrhr promoter. Indeed, mutation of each E-box in the mouse promoter resulted in full or severe decrease in promoter activity as measured by transient transfection assays using the $\alpha \mathrm{T} 3-1$ gonadotrope cell line (Resuehr et al., 2007). One at least out of the three most 
proximal E-boxes (E-box 1, 2, and 3), binds the CLOCK (circadian locomotor output cycles kaput) transcription factor as demonstrated by ChIP assay. This strongly suggested that the mouse promoter is under the control of CLOCK/BMAL1 (brain and muscle arnt-like protein 1) heterodimer. In addition, transcripts encoding Drosophila homolog of period 1 (PER1), PER2, cryptochrome 1 (CRY1), and CRY2 were detected, signifying that dynamic inhibition by CRY/PER of CLOCK/BMAL1-directed gene transcription may take place in this gonadotrope cell line. Although the actors of the molecular loop essential for rhythmic timekeeping are all present, circadian rhythms of Gnrhr expression were not observed in cultured gonadotrope $\alpha \mathrm{T} 3-1$ cells. Subsequent study considering E-box transcription factors has demonstrated the involvement of two other b/HLH transcription factors, neurogenic differentiation 1 (NEUROD1) and mammalian achaete-scute homolog 1 (MASH1), that both interact with E-box 3, suggesting that the CLOCK/BMAL1 heterodimer bind to either E-box 1 or 2 but not to E-box 3 (Cherrington et al., 2008). Interestingly, the $\alpha \mathrm{T} 3-1$ gonadotrope cell line preferentially expresses NEUROD1 whereas L $\beta$ T2 cells preferentially express MASH1. Consequently, Gnrhr E-box 3 binds NEUROD1 from $\alpha \mathrm{T} 3-1$ cells, but binds MASH1 from L $\beta$ T2 cells. This difference may be related to the differentiation state of these cell lines as mentioned above.

\section{The rat promoter (Figure $2 B$ )}

SF1, CRE, SAP, and AP1 elements in the proximal active domain. The $5^{\prime}$ flanking sequence of the rat promoter has been successively isolated by Reinhart et al. (1997) and by Pincas et al. (1998) in our laboratory. Comparative analyses reveal $82-84 \%$ sequence identity with the corresponding 1.9 and $1.2 \mathrm{~kb}$ mouse promoter region. Sequence homology is well illustrated by dot matrix pairwise alignment of rat versus mouse sequence (Figure 3A). The analysis further reveals full lack of homology beyond $2.1 \mathrm{~kb}$, suggesting that master regulatory domains in rodents are constrained within $2 \mathrm{~kb}$ upstream of the ATG codon. Furthermore, the transcriptional start sites appear similarly clustered within the $110 \mathrm{bp}$ proximal region. A first set of major sites is located between -110 and -103 , depending on the authors and a second set of both major and minor sites is located around position -30 . The rat promoter was proved to be strongly active in $\alpha \mathrm{T} 3-1$ and L $\beta \mathrm{T} 2$ gonadotropederived cells as well as in GT1-7 hypothalamic-derived cell line. Within the proximal domain, two elements that are identical to the AP1 $(-352 /-346)$ and SF1 $(-245 /-237)$ response elements of the mouse promoter are required to mediate gonadotropespecific activity (Pincas etal., 2001a). However, despite these remarkable similarities, the rat promoter displays functional characteristics that distinguish it from the mouse promoter. Two additional response elements are required in the proximal active domain for full cell-specific activity (Granger et al., 2006) a CRE (cAMP response element) element $(-110$ TGACGTTT -103$)$ that binds CRE binding protein (CREB) with a lower affinity than the consensus TGACGTCA sequence (Pincas et al., 2001b) and an element located at $-252 /-245$ that binds a yet unidentified factor referred to as SAP for SF1 adjacent protein. Despite its immediate proximity with the SF1 response element, the SAP element acts independently of SF1. Furthermore, a GRAS-like element is present in the rat promoter but was proved inactive despite the close sequence identity with its mouse counterpart (Pincas et al., 2001a; Cherrington et al., 2005).

Homeodomain factor response elements in the distal and proximal regulatory domains. The distribution of response elements along the promoter constitutes the most important difference between the rat and mouse species. In contrast with the mouse promoter where all known response elements are clustered within the 500 bp proximal region, an additional regulatory region containing a bipartite enhancer that we named Gnrhr-specific enhancer (GnSE) lies on a more distal part of the rat promoter $(-1135 /-753)$. Two major response elements located at positions $-994 /-960$ and $-871 /-862$ are responsible for GnSE action (Pincas et al., 2001a; Granger etal., 2006). Interestingly, GnSE activity is dependent on both cellular and promoter contexts. Maximal activity required the presence of the SF1 response element that lies on the proximal promoter domain, $600 \mathrm{bp}$ downstream. Thus, the GnSE belongs to a class of promoter-specific enhancers, capable of acting at a distance as classical enhancers do, but requiring a specific context, in our case, a SF1 element containing promoter. Regarding the proximal GnSE element (-871/-862), it was found to bind the pair of LIM-HD proteins LHX3 and ISL1 (Granger et al., 2006). This was demonstrated by several convergent approaches, notably using overexpression of the LIM-HD proteins and a LHX3 dominant negative in co-transfection assays, gel-shift and super-shift assays, and DNA affinity chromatography. This element displays high sequence identity in the antisense orientation with the $-363 /-342$ region of the mouse promoter that was itself shown to interact with LHX3 (McGillivray et al., 2005; Cherrington et al., 2006). Using antibodies against LHX3 and ISL1 in ChIP assays, we were able to show that the mouse sequence did recruit ISL1 in addition to LHX3 (Schang et al., 2012b) as already demonstrated by McGillivray et al. (2005). Nevertheless, deletion of the LIM-HD response element in the rat promoter does not fully abolish the trans-acting effect of the ISL1/LHX3 pair. This led us to identify the upstream element of the GnSE as a second LIM-HD response element. It displays similar properties and specificity as the first characterized one (Schang et al., 2012b). These elements were then referred to as proximal and distal LIM-HD response elements, P-LIRE and D-LIRE, respectively. Finally, recent work from our laboratory has permitted to the identification of a prophet of PIT1 (PROP1)/orthodenticle drosophila homolog 2 (OTX2) response element in the proximal regulatory domain of the rat promoter, located at $-368 /-357$. Interestingly, OTX2 (or OTX1) stimulates promoter activity in synergy with PROP1 by interacting with this element in gonadotrope-derived cell lines. In contrast, in non-gonadotrope cells, notably in the neutral Chinese hamster ovary $(\mathrm{CHO})$ cell line, OTX2 acts synergistically with CREB through another OTX2 response element involving a ATTA core motif located at position $-163 /-160$, close to the CRE element (Schang et al., 2012a).

\section{Negative regulatory elements in the proximal part of the mouse promoter}

As underlined above, the GH3 lactosomatotrope-derived cell line expresses the mouse promoter at a low but detectable level. The 
A

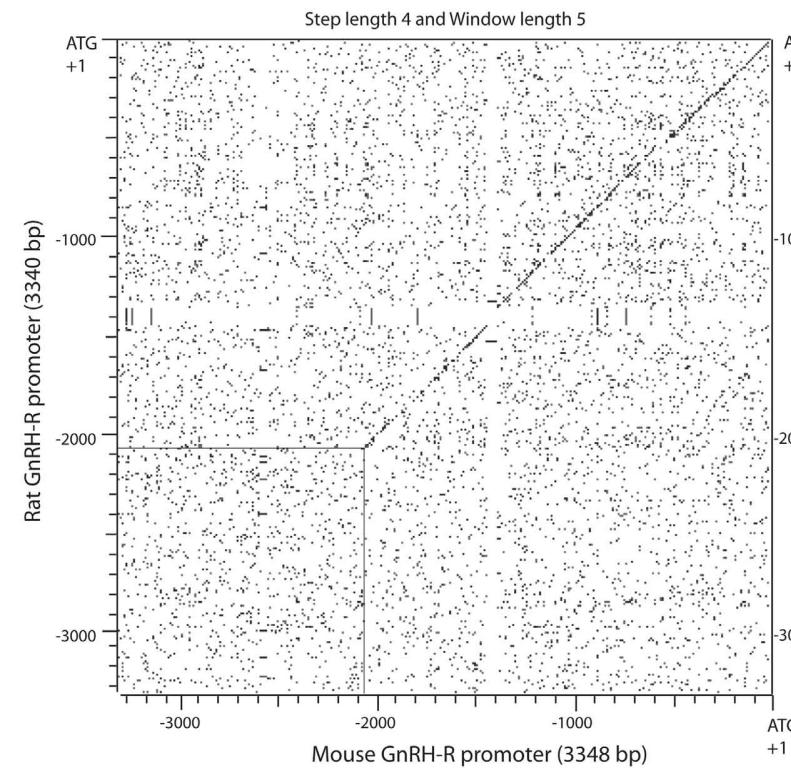

B

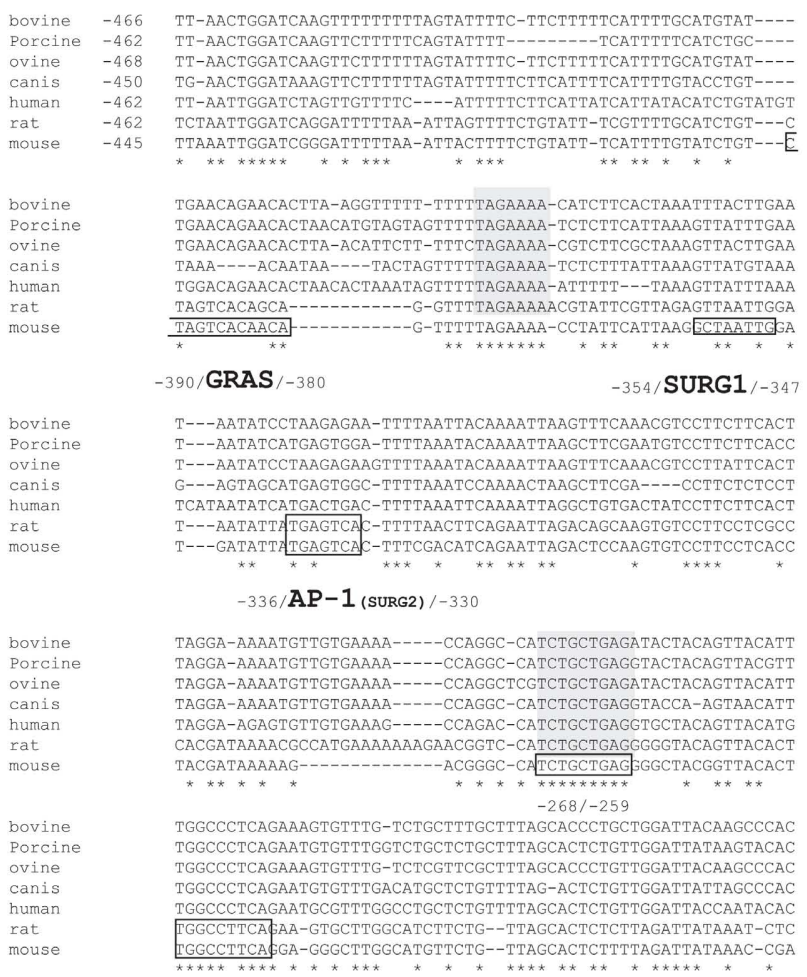

$-243 / \mathbf{S F}-1 /-235$

FIGURE 3 | Sequence comparison of Gnrhr promoters in different mammalian species. (A) Dot matrix representation of pairwise alignment of rat versus mouse (left panel) or human (right panel) sequences. A strong sequence conservation between mouse and rat $5^{\prime}$ upstream flanking regions extends over $2 \mathrm{~kb}$ whereas that between rat (or mouse) and human sequences is limited to a proximal $0.5 \mathrm{~kb}$ region upstream of the ATG codon. Relaxed sequence identity between rat and human sequences is further observed between 0.5 and $1.2 \mathrm{~kb}$ upstream of the ATG codon. (B) Multiple

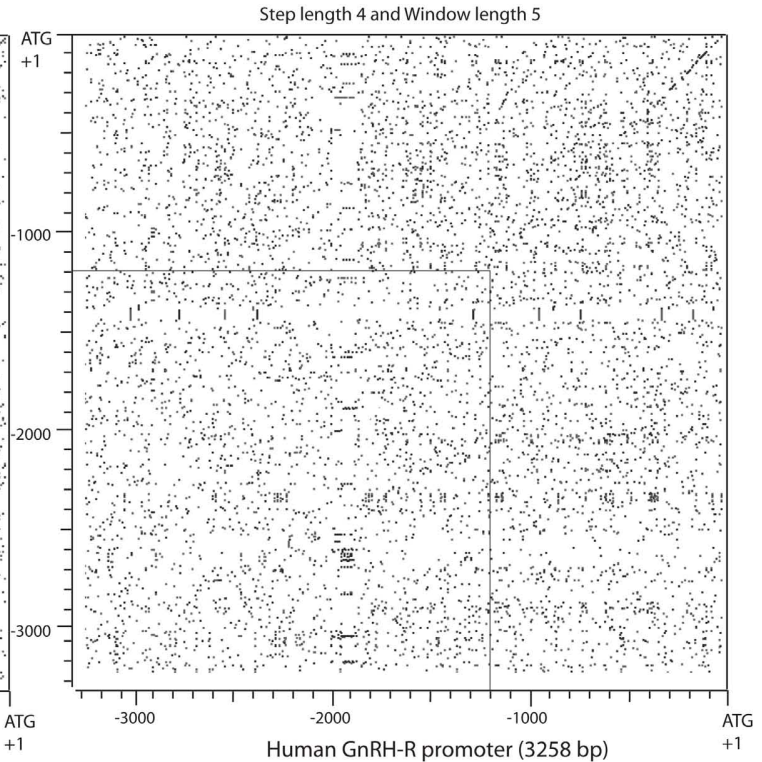

Human GnRH-R promoter (3258 bp) bovine

Porcine

ovine

human

rat

rat

bovine

Porcine

ovine

canis

huma

rat
mouse

AAAACAAGTTCACCTTGATCTTTCACTTTAAATACAA-AATATCTCAGGGACAA--AATT AAAACAAGTTCACCTTGATCTTTCACATTAAAATATAA-AGCATCTCAGGGACAA--AATT AAAACAAGTTCACCTTGATCTTTCACATTAAATATAA-AGCATCTCAGGGACAA--AATT AAAACA GTCACCTGATCTTTCACTTTAAATACAA-AGTATCICAGGGACAA--AAT' AAAACAAGITCACCTTGATCTTTTATGTTAAACATAA-AGTAGCTCAGGGACAA--AATI AAAACAAGTTAACCTTGATCTTTCACATTAA------GTATdTCAGGGACA A--AATT AAAACAAGTTTACCTTGATCTTTCACGTTAAGTCCAG-AGTATCTTGGGAAAAATAAATT

$-134 / \mathbf{S F}-\mathbf{1} /-142$

TGACATAAATATAAACCTGTGACGTTATCAGCCAAAGAAGGCTGAAATAAAACAGGACTC TGACATAAATATAAACCTGTGACGTTTCCATCTAAAGAAGACTGAAATAAA-CAGAATTC TGACATAAATATA.AACCTGTGACGTTACCAGCCAAAGA.AGGCTGAAATAAAACAGGACTC TGACATAA-----ACCTATGACGCTTCCATCTAAAGAAGGCAGAAATAAAACGGAGCTG TGACATACGTCTAAACC TGACATAAATGTAAGCCT TIGACGTTTCCCTCTAAAGAAGGCAGAAAGCAA-CAGCGCTT AGGCAGAAATGCTAACCT TGACGTITCCATCTAAAGGAGGCAGACATCAA-CAGCGCTIT

$$
-109 / \mathbf{C R E} /-102
$$

bovine porcine

CAAGTGCAATTACAATAAAAT-ATCAGAAGTGCCAGAAACACGAGTCTTGAAGCTGCATC TGGGTTCAATTATAATAAAACCAGCAGAAGTACTAGAAACAGGAGTCTTGAAGCTACATC CAAGTGCAATTACAATAAAAC-ATCAGAAGTGCCAGAAACACGAGTCTTGAAGCTGTATC TGGGCTAGATTACAATAAAAC-ATCAGAAGCGCCAGAAACACAAGTCTTGAAGCTCCATC TAGATTCGGTTACAATAAAAT-ATCAGATGCACCAGAGACACAAGGCTTGAAGCTCTGTC TGCGTTCAGTTACGATAAAAACATCAGCAGTAACAGAGACTCGACTCTTGAAGC-CCGTC CGCGTTCAGTTATGATAAAA-CATCAGAAGTAACAGGGACTCCACTCTTGAAGC-CTGTC

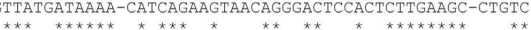

AGCCATA-AAG AFG

AGTTGGGGAG $\$ A$ TE

AGCCATA-AAGAAF

AGTAAGG-AAA AFE

--CTGGGAAAA TAP

C-TTGGAGAAA AF

C-TTGGAGAAA AFG

$+1$ sequence alignment of mammalian Gnrhr proximal promoters. Blocks of full identity are highlighted in gray. Some motifs of interest are boxed in the sequences of the species where they have been characterized (e.g., SURG1 in the mouse, AP1 in rat and mouse). Note that the SF1 response element characterized in the rat and mouse promoter sequences $(-243 /-235)$ is particularly well conserved among species contrasting with the human SF1 response element $(-134 /-142)$. The latter appears to be shared by bovine, porcine, ovine and canis species but not by rat and mouse. 
stably transfected GGH(3) cell, first designed in order to evaluate GnRH action, was thereafter used to identify the elements that allow constitutive expression in this non-gonadotrope, SF1lacking cell line (Maya-Nunez and Conn, 1999). A CRE element (-109 5'-TGACGTTT-3' -102$)$ contributed to basal promoter activity, suggesting that constitutive activation of the PKAdependent signaling pathway may also participate in cell-specific activity in pituitary gonadotropes as well as in other GnRHR expressing tissues. Importantly, several negative regulatory regions were identified $(-213 /-207 ;-268 /-259 ;-354 /-342)$ that may serve to repress the activity of the Gnrhr in non-gonadotrope pituitary cells. Among them the -268/-259 (5'-TCTGCTGA$\left.3^{\prime}\right)$ region is strictly conserved among bovine, porcine, ovine, canis, human, rat, and mouse sequences (Figure 3B). However, the inhibitory effects of these sequences are modest and cannot account for the whole lack of Gnrhr expression in nongonadotrope pituitary cells. Furthermore, they partially overlap regulatory regions characterized as positive in a gonadotrope cell context.

\section{RESPONSE ELEMENTS INVOLVED IN TISSUE-SPECIFIC MOUSE AND RAT PROMOTER ACTIVITY ARE ALSO INVOLVED IN REGULATION BY EXTRA-CELLULAR SIGNALS}

It is often noticed that tissue-specific transcription factors participate either directly or as co-regulators in the modulation of promoter activity by extra-cellular signals. This is also true for the rodent Gnrhr since, as we shall see in more detail below, SF1 is involved in PACAP- and PKA-regulated activity, AP1 in the homologous up-regulation by GnRH, and GRAS in the up-regulation by activin.

\section{GnRH homologous up-regulation in gonadotrope-derived cells (Figure 4)}

Two independent studies using transient transfection in $\alpha \mathrm{T} 3-1$ cells demonstrated a time- and dose-dependent increase in the activity of the mouse Gnrhr promoter under GnRH treatment (Norwitz etal., 1999b; White etal., 1999). By using $3^{\prime}$ and $5^{\prime}$ deletion analyses combined with functional transfection studies, White et al. (1999) showed that a 54 bp fragment extending from -370 to -326 and thus including the AP1 element was sufficient to mediate GnRH response when placed upstream of a minimal heterologous promoter. Further analysis by Norwitz et al. (1999a) using linker scanning mutagenesis led to identifying two sequences of $8 \mathrm{bp}$, SURG-1 (sequence underlying responsiveness to GnRH-1; -354/-347) and SURG-2 (-338/-331) that are necessary for full GnRH responsiveness (Figure 3B). The SURG-2 element corresponds to the AP1 element and is absolutely required since mutations within this sequence totally abolished GnRHinduced stimulation of promoter activity whereas mutations within the SURG-1 element (5'-GCTAATTG-3') only attenuated the response. Based on targeted mutagenesis of each of the GRAS, AP1, and SF1 elements that compose the tripartite basal enhancer, the study by White et al. (1999) has led to a rather similar conclusion regarding the AP1 element involvement. Both studies, using antibodies directed against conserved protein domains of either the JUN or FOS families in electrophoretic mobility shift assays strongly suggest that an AP1/DNA complex mediates
GnRH homologous up-regulation. The MAPK kinase (MEK1/2) inhibitor PD98059 abrogates both GnRH-induced stimulation of promoter activity and GnRH-induced phosphorylation of extracellular signal-regulated kinases (ERK) 1 and 2 (White et al., 1999) and of c-Jun N-terminal kinase (JNK; Ellsworth et al., 2003b). GnRH induction of mouse Gnrhr promoter activity may thus require functional activation of a $\mathrm{PKC}$-dependent pathway that involves the ERK- or JNK-signaling cascade or both and ultimately converges to AP1. However, accurate analysis of the intracellular events induced by GnRH treatment of $\alpha \mathrm{T} 3-1$ cells strongly suggested that the JNK-signaling cascade is predominantly involved (Ellsworth et al., 2003b). Accordingly, in pituitarytargeted ERK1/2 double-knockout mice, Gnrhr expression was not altered as compared with wild-type animals (Bliss et al., 2009), suggesting that ERK signaling is not primarily involved in gonadotrope-specific expression of the Gnrhr. Moreover, the activation of the JNK-signaling cascade induced post-translational modifications of FOSB and JUND that led to increased binding of both factors on the SURG-2, the AP1 response element of the Gnrhr promoter (Ellsworth et al., 2003b). More recently, the factors that interact with SURG-1 have been identified as OCT1 and NFY. They are not only involved in the tissue-specific expression as mentioned above but also in $\mathrm{GnRH}$ homologous up-regulation. ChIP assays demonstrated that both factors are recruited on the mouse promoter in a time-dependent manner after GnRH treatment (Kam et al., 2005). It is important to point out that, in the context of the 600 bp mouse promoter, the adenylate cyclase activator forskolin inhibits GnRH-induced stimulation, suggesting a cross-talk between these two pathways (White et al., 1999). However, in the context of the chimera promoter made up with the mouse $-370 /-326$ bp promoter fragment linked to the minimal GH heterologous promoter, forskolin is inefficient even if the $\mathrm{GnRH}$ response is maintained. This may indicate that the cross-talk takes place at the promoter level and requires response element(s) that are present within the $600 \mathrm{bp}$ mouse promoter fragment and absent from the $-370 /-326$ bp promoter fragment, notably the CRE element located at $-109 /-102 \mathrm{bp}$.

\section{GnRH homologous up-regulation in non-gonadotrope cells (Figure 4)} The GnRHR is known to be expressed in several extra-pituitary tissues, notably in some areas of the brain, as well as in gonads and placenta. In this regard, it is important to consider the modalities of expression and regulation of the Gnrhr in cells distinct from gonadotropes. The availability of the stably transfected GGH3 cell line has permitted evaluating GnRH action on the transfected mouse promoter in a non-gonadotrope context. Consistent with the data obtained with $\alpha \mathrm{T} 3-1$ cells, the activity of the mouse promoter was significantly increased in GGH3 cells following GnRH treatment (Lin and Conn, 1998). Subsequent analysis suggested that GnRH action is likely mediated by both PKA- and PKC-dependent signaling pathways (Lin and Conn, 1998, 1999; Maya-Nunez and Conn, 1999, 2001). Accordingly, GnRH stimulation was partly prevented by the adenylate cyclase inhibitor SQ22536 while treatment with the PKC inhibitor GF109203X led to nearly complete blockade. These data are in accordance with other results obtained using cholera toxin or cAMP analogs as well as following treatment with phorbol ester (Lin and Conn, 


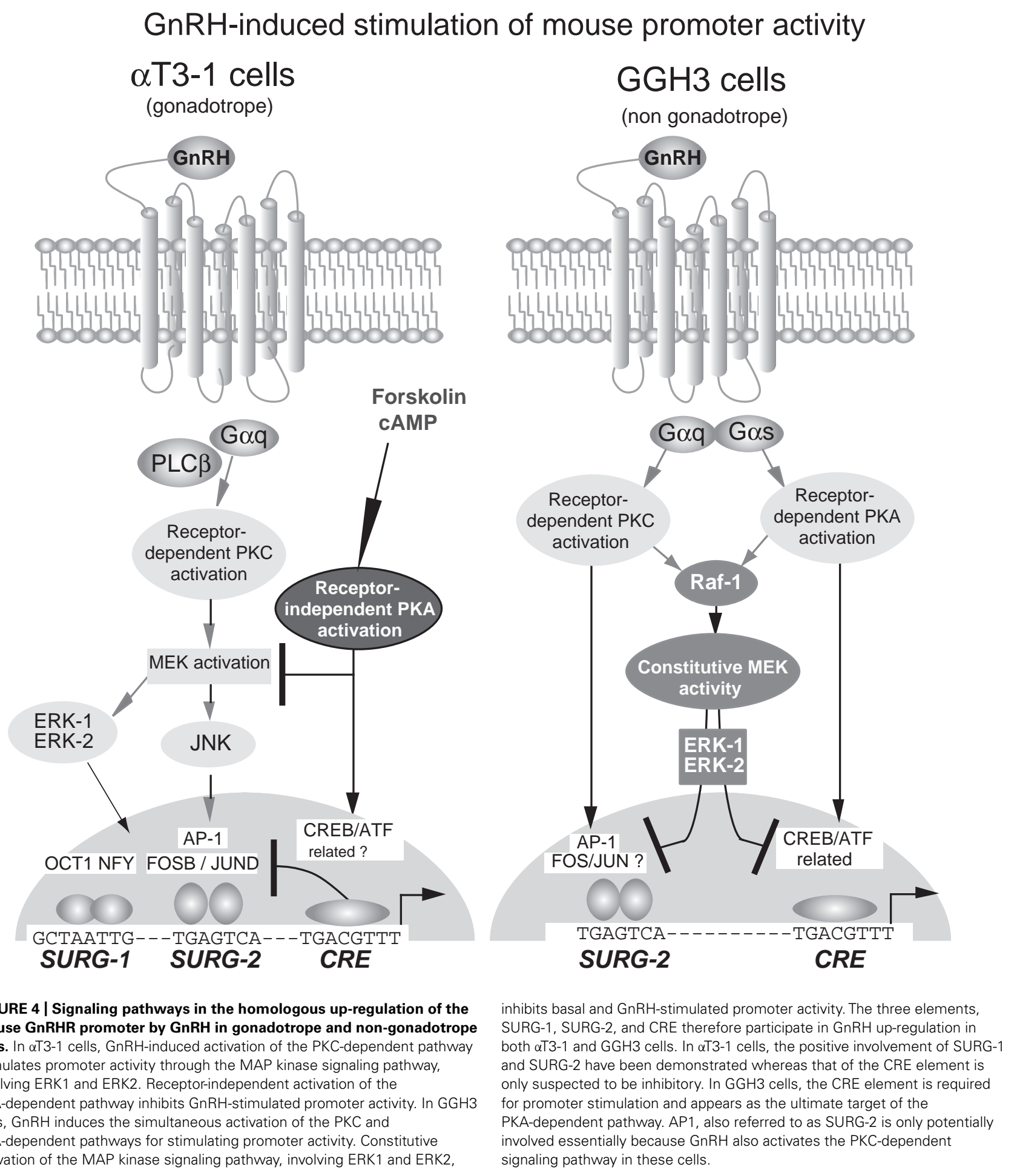

1998, 1999). It is important to specify that all these treatments resulted in the stimulation of the MAPK pathway in GGH3 cells (Han and Conn, 1999). However, agents that inhibit the activation of the MAPK pathway such as the drug PD98059 or ERK1 and ERK2 mutants together increased both tissue-specific and GnRH-stimulated promoter activity. Conversely, transfection of vectors expressing agents that mimic the activation of the MAPK pathway such as Raf1 or wild-type ERK1 and ERK2 inhibited tissue-specific and GnRH-stimulated promoter activity. Altogether, these data indicate that activation of the MAPK pathway is inhibitory in the lactosomatotrope GGH3 cell line whereas it is stimulatory in gonadotropes. Furthermore, GnRH action in 
GGH3 cells resulted in two opposite effects on the activity of the mouse Gnrhr promoter: a negative effect through the activation of the MAPK pathway and a positive one through the activation of PKA- and PKC-dependent pathways. The CRE element $(-109 /-102)$ that is involved in tissue-specific activity seems to be also involved in the GnRH and PKA-dependent regulation. The stimulatory effect of GnRH was indeed partially abolished and that of cAMP analog fully abrogated by targeted mutations of the CRE element. It is then rather probable that GnRH action also occurs through the SURG2 element in GGH3 cells.

\section{Activin up-regulation}

Activin, a member of the transforming growth factor- $\beta$ superfamily, has first been shown to enhance the GnRH-induced FSH and LH release and to enhance the rate of GnRHR synthesis in rat pituitary cells (Braden and Conn, 1992; Weiss et al., 1993). This led to question its potential action at the transcriptional level. Exogenous activin B treatment of $\alpha$ T3-1 cells was shown to increase Gnrhr promoter activity as demonstrated by nuclear run-off assays or after transient transfection of the $1.2 \mathrm{~kb}$ mouse promoter linked to the luciferase reporter gene (Fernandez-Vazquez et al., 1996). However, since $\alpha$ T3-1 cells and pituitary gonadotropes both produce activin $\mathrm{B}$, responsiveness to activin has then been mainly monitored by follistatin-induced inhibition of activin action in subsequent analyses (Duval et al., 1999). Using transient transfection in $\alpha$ T3-1 cells, follistatin inhibition of promoter activity was demonstrated to be mediated through the GRAS element. Indeed, mutation of this motif abrogated follistatin inhibition whereas alteration of the SF1 or AP1 elements was minimally efficient. Consistent with these results, three copies of the GRAS element were sufficient to confer activin responsiveness to a minimal heterologous promoter. The GRAS motif also exhibits sequence similarities with the element (GTCTAGAC) that binds the receptor-activated SMAD2/SMAD3 and the common SMAD4 (Stopa et al., 2000), involved in activin signaling (Walton et al., 2012). The autocrine/paracrine action of activin also explains why the GRAS motif has been classified as a paracrine/autocrine cell-specific response element. Comparison with the rat promoter sequence that does not exhibit activin responsiveness led to the characterization of a second region involved in activin-mediated up-regulation of the mouse promoter, a region referred to as "downstream activin regulatory element" or DARE (Cherrington et al., 2005). This 18 bp-long region lies between -366 and -349 and overlaps LHX3, OCT1, and NFY response elements. However, none of these factors seems to be involved in activin responsiveness. The integrity of the two TAAT motifs identified in this sequence was mandatory for functional DARE. Furthermore, appropriate helical orientation of this region relatively to the GRAS element located $20 \mathrm{bp}$ downstream is required suggesting that factors that bind to DARE interact with GRAS binding factors (SMAD, AP1, FOXL2; Cherrington et al., 2006).

Norwitz et al. (2002a,b) have investigated the potential synergy between $\mathrm{GnRH}$ and activin treatment on the mouse promoter activity. They found that activin was able to increase the stimulatory effect of $\mathrm{GnRH}$ by approximately twofold. Interestingly, deletion of the promoter region that contains the GRAS element as well as mutation that alters the $5^{\prime}$ part of the GRAS element abrogated the effect of activin on GnRH stimulation. They also showed that overexpression of SMAD4 together with SMAD2 or SMAD3 increased both tissue-specific promoter activity and $\mathrm{GnRH}$ homologous up-regulation. However, it remains to be established if mutation of the presumed Smad binding element (SBE box -393/-386) in the GRAS element may prevent the stimulatory effect induced by SMAD overexpression. Competition and super-shift experiments further indicated that a second factor, belonging to the AP1 family, may bind the $3^{\prime}$ part of the GRAS element, suggesting that JUN/FOS related factors and SMAD protein functionally interact.

\section{PACAP up-regulation}

Specific type 1 receptors for PACAP are present in gonadotrope cells of the anterior pituitary gland as well as in mouse gonadotrope-derived $\alpha \mathrm{T} 3-1$ cells. By transient transfection in $\alpha$ T3-1 cells, Pincas et al. (2001b) provided evidence that PACAP stimulates rat Gnrhr promoter activity. The EC50 of this stimulation was compatible with PACAP activation of the cyclic AMPdependent signaling pathway and, consistently, co-transfection of an expression vector expressing the PKA inhibitor caused reduction in PACAP - as well as cholera toxin -stimulated promoter activity. Deletion and mutational analyses indicated that PACAP activation necessitated a bipartite response element that consists of a first region $(-272 /-237)$ termed PACAP response element (PARE) I that includes the SF1-binding site and a second region $(-136 /-101)$ referred to as PARE II that contains the CRE (TGACGTTT). Gel-shift experiments revealed that SF1 and SAP together bind to PARE I while a protein immunologically related to the CREB interacted with PARE II. Altogether, these findings indicated that PACAP regulates the rat Gnrhr at the transcriptional level in $\alpha \mathrm{T} 3-1$ cells. Interestingly, the mouse promoter was similarly proved to be regulated by PACAP (Sadie et al., 2003). However, the response elements were not identified, nor were those involved in the PKA-induced stimulation of the mouse promoter. Notably, the ability of the CRE located at $-109 /-102$ (i.e., equivalent to the rat promoter one) to mediate the PKA-dependent stimulation of the mouse promoter was not assessed. Nevertheless, two other response elements were shown to modulate PKA responsiveness (Sadie et al., 2003), the SF1 response element and a newly identified response element located at $-15 /-7$, close to the translation initiation site (ATG). Both elements were able to bind NUR77 (NR4A1) and SF1 and exerted opposite effects. Mutation of the element close to the ATG codon together with overexpression of SF1 dramatically amplified PKA-induced stimulation. In contrast, overexpression of NUR77 repressed PKA-dependent regulation, most probably through the $-15 /-7$ element. PACAP has been shown to stimulate follistatin (Fst) gene expression which restrains activin signaling and thus represses Fshb and Gnrhr expression as well as other activin-responsive genes. Therefore, in mouse gonadotrope cells, the PACAP direct stimulatory effect on Gnrhr promoter may be weakened by the indirect inhibitory action of PACAP on activin-stimulated promoter activity. The rat promoter is not submitted to this down-regulation because both the GRAS element and the DARE region are inactive. Whether PACAP regulation also occurs in vivo and is a common trait in mammals remains to be elucidated however. 


\section{FUNCTIONAL CHARACTERISTICS OF THE HUMAN Gnrhr PROMOTER IN VITRO}

The human Gnrhr promoter has been independently isolated by two groups (Fan et al., 1995; Kakar, 1997). It displays several features that distinguish it from rodent promoters (Cheng and Leung, 2005). Firstly, a significant sequence identity with the above-described promoters does not extend beyond approximately -1200 bp from the ATG codon (Figure 3A). Secondly, in contrast to the rodent promoters, the transcription start sites are located far upstream of the ATG codon and disperse within two domains localized between -578 and -826 and between -1347 and -1751 , indicating the existence of two core promoter regions (Fan et al., 1995; Kakar, 1997). A further difference with mouse and rat promoters is the presence of several TATA boxes well scattered among the transcription start sites, suggesting that transcription initiation occurs through different mechanisms in rodent and human.

Given that GnRHR is expressed in several tissues in addition to the pituitary gland, functional studies with the human promoter have been performed in non-pituitary cell lines, notably cells derived from placenta, endometrium, trophoblast, and ovary. This strategy has also been motivated by the absence of pituitary cell line of human origin. These studies led to the discovery of several positive and negative regulatory regions, the efficacy of which being strongly dependent on the considered cell line. They essentially confirmed the existence of distinct promoters within the $2 \mathrm{~kb}$ human $5^{\prime}$ flanking sequence.

\section{The proximal core promoter is predominantly active in gonadotrope-derived cells (Figure 5A)}

Following transfection in $\alpha \mathrm{T} 3-1$ cells, it appeared that crucial elements are located in the close vicinity of the translation start codon because the $-173 /+1$ deletion abolished promoter activity (Ngan et al., 1999; Kang etal., 2000). Targeted mutagenesis of a SF1 response element located at $-142 /-134\left(5^{\prime}\right.$-CAGGGACAA- $\left.3^{\prime}\right)$ altered overall promoter strength suggesting that it is likely contributing to the gonadotrope-specific activity. The involvement of SF1 has been further evidenced by electrophoretic mobility shift and super-shift assays as well as by overexpression of SF1 (Ngan et al., 1999). However, silencer elements present in the middle part of the human promoter $(-1018 /-707)$ weaken promoter strength. Indeed, $5^{\prime}$ deletion to -707 increased tissuespecific activity in $\alpha \mathrm{T} 3-1$ cells, the deleted promoter $(-707 /+1)$ being approximately threefold more active than the entire promoter (-2200/+1; Cheng and Leung, 2001). These data are in agreement with the existence of a proximal core promoter region $(-816 /-577)$ previously documented (Fan et al., 1995) and with the presence of a positive regulatory region $(-771 /-557)$ identified by $3^{\prime}$ deletion analysis (Kang et al., 2000). This also suggests that positive regulatory regions either overlap the core promoter region or are situated downstream from the transcription start sites as is the SF1 element cited above. Subsequent analysis by scanning mutations in $\alpha \mathrm{T} 3-1$ cells has allowed precise delimitation of this proximal promoter that extends from -607 to -568 . It contains two pyrimidine-rich initiator elements $(-602 /-597$ and $-589 /-584)$ that bind similar proteins notably TFIID (Hoo et al., 2003). The distal promoter of the human gene is constitutively active in both gonadotrope and non-pituitary cell lines (Figure 5B).

The existence of a distal promoter active in non-pituitary cell lines has been strongly suggested in the early study by Kakar (1997). In this work, it is indeed shown that the $-2300 /-1020$ human flanking sequence is highly active in human endometrial (HEC-1A) and breast tumor cell (MCF-7) lines. This upstream promoter was further characterized in either gonadotrope or nonpituitary cells by Ngan etal. (2000) and Cheng etal. (2001a), respectively. It appears to be less active in $\alpha \mathrm{T} 3-1$ pituitary than in JEG-3 placental cells (Cheng et al., 2001a) and thus contrasts with the core proximal promoter that displays opposite characteristics. Also, the distal promoter seems to be more ubiquitous than the proximal promoter since it was active in gonadotrope, ovarian, endometrial, mammary, placental, and kidney cells. The in-depth analysis of the distal promoter in gonadotrope-derived $\alpha \mathrm{T} 3-1$ cells (Ngan et al., 2000) and placental JEG-3 cells (Cheng et al., 2001a) reveals cell-specific differences.

In gonadotrope-derived cells, the active elements of the upstream promoter are located within a $-1705 /-1674$ region and are not functional in the reverse orientation. They consist of a pyrimidine-rich initiator $(-1685 /-1676)$ and additional upstream motifs $(-1705 /-1687)$ that include a CCAAT box. Multiple proteins ranging from 40 to $54 \mathrm{~K}$ are capable of binding this upstream promoter. Interestingly, a downstream silencer element $(-1674 /-1577)$ prevents upstream promoter activity, at least in gonadotrope cells. This silencer is efficient only when positioned downstream of the promoter in either reverse or forward orientation. Two sequence-specific repressor motifs of 28 and 8 bp $(-1670 /-1643$ and $-1630 /-1623)$ are essential for silencer activity as evidenced by linker-scanning mutagenesis and gel mobility shift assays (Ngan et al., 2001).

In JEG-3 and IEVT placental cell lines, a similar organization seems to occur, combining positive regulatory sequence and downstream silencer, however with different localization and distinct response elements (Cheng et al., 2001a). The placental cell-specific upstream promoter is located within a $-1737 /-1346$ region and thus overlaps the gonadotrope cell-specific promoter. In JEG-3 cells, four motifs related to OCT1 (-1718/-1710), CRE (-1649/-1641), GATA $(-1602 /-1597)$, and AP1 $(-1518 /-1511)$ response elements are contributing to promoter activity. The characterization of these motifs has been further assessed by gel mobility shift and antibody super-shift assays. The downstream silencer is located between -1017 and -771 and abrogates upstream promoter activity in a manner similar to what is observed with the gonadotrope promoter. The silencer was further characterized in the context of the $-1300 /-1018$ promoter described below. Under these conditions, it appeared that most of the silencing activity of this negative regulatory element resides in an octamer responsive sequence activated by OCT1 (Cheng et al., 2002b).

\section{Distal promoter usages in granulosa and neuronal cell lines}

A third distal promoter was characterized in human ovarian granulosa-luteal cells. It extends from -1300 to -1018 and exhibited the highest promoter activity in SVOG-4o and SVOG$4 \mathrm{~m}$ immortalized granulosa-luteal cells (Cheng etal., 2002a). 


\section{A \\ Human proximal promoter}

Gonadotrope-specific promoter (-607/-568) with two Inr at -602/-597 and -589/-584

TSS (transcription start sites $-826 /-578$ )

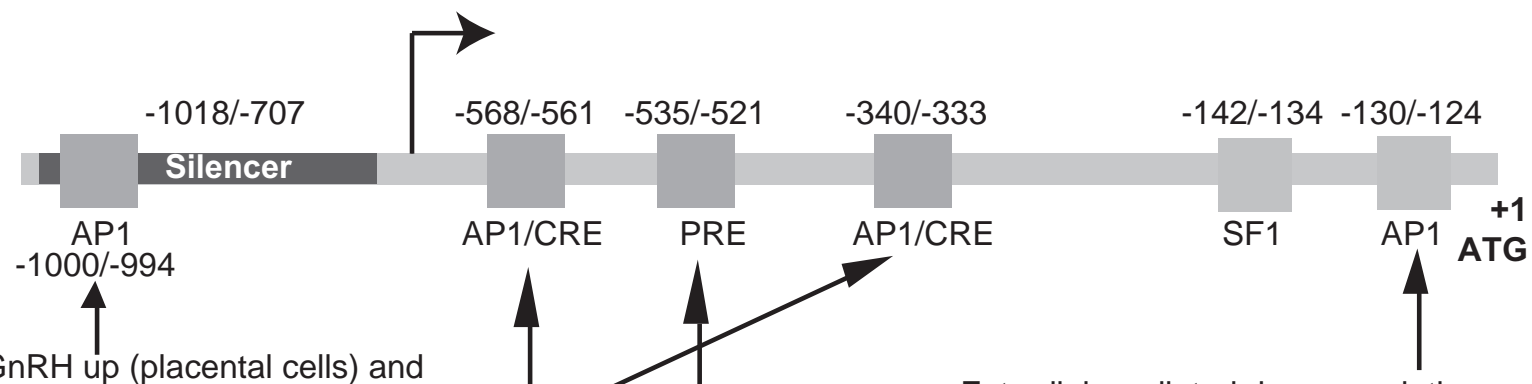
down (gonadotrope cells) regulation

PACAP and PKA

Estradiol-mediated down regulation dependent regulation

in ovarian and breast cancer cells

Progesterone up (placental cells) and

B down (gonadotrope cells) regulation

\section{Human distal promoter}

a - Gonadotrope cells

$-2300$

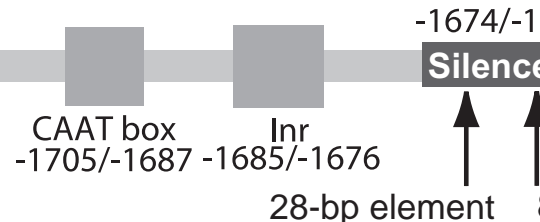

$-1670 /-1643 \quad-1630 /-1623$
PACAP up-regulation

$-1676 /-1648$

$-1020$

\section{b - Placental cells}

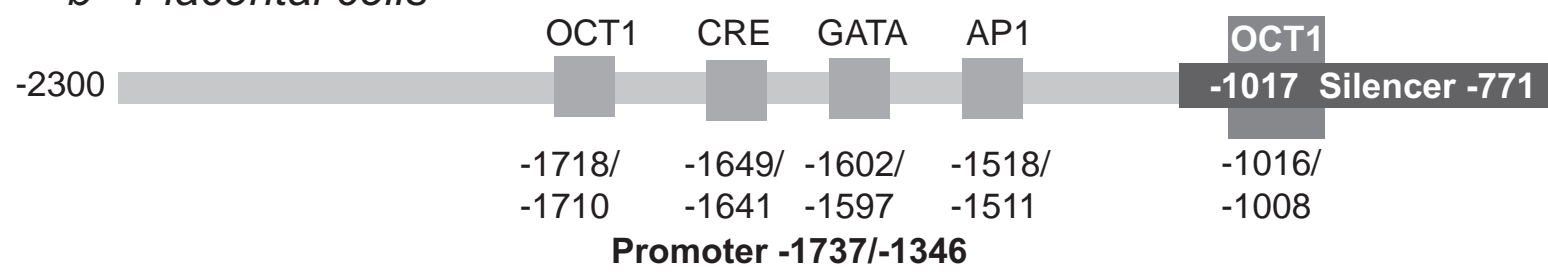

c - Granulosa cells

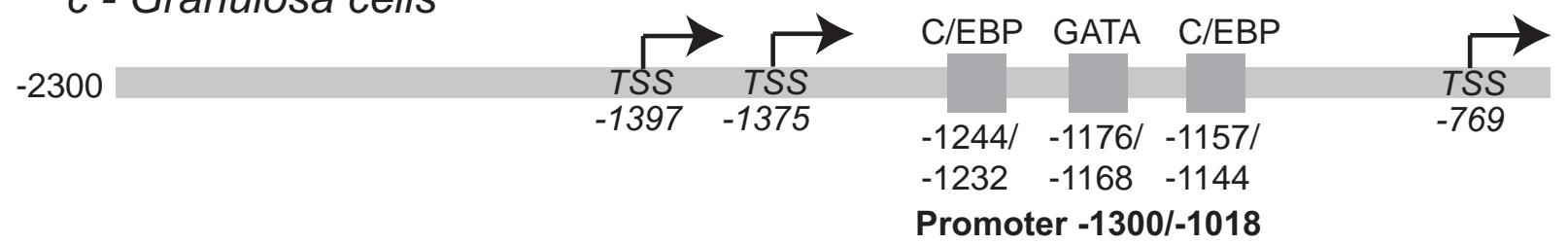

FIGURE 5 | Structure of the human GnRHR promoter. The elements identified in the proximal (A) and distal (B) promoter of the human gene and involved either in the tissue-specific or regulated activity are indicated. To facilitate comparison with the rodent promoters, the first nucleotide of the ATG codon was considered as position +1 . The numbering may therefore be different from that used in the original publications. 
However, it was also active in placental, ovarian, and gonadotrope cells. Two CCAAT enhancer binding protein (C/EBP) located at $-1244 /-1232$ and $-1157 /-1144$ and one GATA response element located at $-1176 /-1168$ were required for full promoter activity because simultaneous mutations of these three elements led to more than $75 \%$ decrease in promoter activity in granulosa cells. Interestingly, the same mutations induced minimal or no significant decrease in promoter activity in ovarian, placental, and gonadotrope cells suggesting that different response elements and different transcription factors are involved in these cell contexts.

Human GnRHR was further expressed in the human cerebellar medulloblastoma cell line TE-671. In these neuronal cells, promoter activity was dependent on an upstream region located between -2197 and -1018 . Important cis-acting regulatory elements were identified at $-1300 /-1018$ and $-2197 /-1900$, as deletion of either region induced a dramatic decrease in promoter activity (Yeung et al., 2005).

\section{REGULATION OF HUMAN PROMOTER ACTIVITY BY EXTRACELLULAR SIGNALS (FIGURE 5) \\ Homologous up- and down-regulation by GnRH and the PKC-dependent pathway}

Surprisingly, when compared to rodents, a 6-24 h-long treatment with $0.1 \mu \mathrm{M}$ GnRH reduced activity of the $2.3 \mathrm{~kb}$ human $G n R H R$ promoter by $31-71 \%$ in $\alpha \mathrm{T} 3-1$ cells. This inhibitory effect was mimicked by phorbol ester and prevented by GnRH antagonists or specific PKC inhibitors (Cheng et al., 2000) strongly suggesting that $\mathrm{GnRH}$ action is mediated through receptor-dependent activation of the PKC pathway. Subsequent $5^{\prime}$ deletion analyses combined with site-directed mutagenesis revealed that an AP1 related element located at $-1000 /-994$ (TTAGACA) is responsible for the homologous down-regulation of promoter activity by forming an AP1 complex involving the c-JUN and c-FOS protooncogenes. This AP1 element is unrelated to the AP1/CRE element involved in tissue-specific expression. It is worth stressing that similar GnRH treatment applied to placental JEG-3 or IEVT cell lines led to significant increases in promoter activity, contrasting again with data obtained in gonadotrope-derived cells (Cheng et al., 2000). The mechanisms underlying these positive and negative regulations remain to be elucidated, notably whether differential promoter usage (upstream versus proximal) may be related to such difference in GnRH regulation.

\section{Up-regulation by PACAP and PKA-dependent pathway}

The regulation of the human promoter by PACAP and the PKA-dependent activation pathway has been investigated in two different studies and led to the identification of distinct regulatory domains located within either the upstream or the proximal promoter, respectively (Cheng and Leung, 2001; Ngan et al., 2001). The former study (Ngan et al., 2001) indicated that both the gonadotrope cell-specific upstream promoter as well as the downstream silencer are involved in PACAP and PKA-dependent regulation. In support, PACAP treatment enhanced the formation of a complex with the 28 bp sequence-specific repressor motif (see above). Whether this may contribute to suppress silencer function and in turn to activate promoter remains to be demonstrated. The mechanisms underlying this positive regulation are not yet clearly identified. The latter study by Cheng and Leung (2001) led to the conclusion that PACAP and CREs reside within a 412 bp fragment $(-577 /-167)$ of the proximal promoter. Indeed, mutation of the (-568/-561 and $-340 /-333)$ AP1/CRE related motifs nearly abrogated the stimulation.

\section{Up- and down-regulation by steroid hormones}

Similarly to $\mathrm{GnRH}$, progesterone treatment led to either inhibition or stimulation of promoter activity in gonadotrope versus placental cells, respectively (Cheng et al., 2001b). A progesterone binding site located at -535 to -521 has been shown to mediate, at least partially, both the inhibitory and stimulatory action of progesterone. Overexpression of the human progesterone receptor $\mathrm{A}$ and $\mathrm{B}$ isoforms increased the negative effect of progesterone in $\alpha \mathrm{T} 3-1$ cells, whereas only B isoform mediated its positive action in JEG-3 placental cells. It is important to point out that the A isoform mediated inhibitory action in both cell lines, suggesting that the balance in the expression of A and B isoforms may be critical for GnRHR expression in the pituitary. The involvement of the progesterone receptor in binding the $-535 /-521$ motif has been further substantiated by gel-shift and antibody super-shift assay.

In OVCAR3 ovarian carcinoma and MCF7 breast carcinoma cell lines, $\mathrm{E}_{2}$-induced repression of Gnrhr promoter activity through an $\mathrm{E}_{2}$ receptor $\alpha(\mathrm{ER} \alpha)$-mediated mechanism (Cheng et al., 2003). This occurred in a dose- and time-dependent manner, the maximal effect being obtained at $10^{-8} \mathrm{M} \mathrm{E}_{2}$ after a $48 \mathrm{~h}$ long treatment ( $80 \%$ reduction of promoter activity). Repression occurred via an AP1-like element located at position -130/-124. This element was able to bind c-FOS and c-JUN but not ER $\alpha$ as demonstrated by EMSA. DNA binding by ER $\alpha$ was not needed for the $\mathrm{E}_{2}$ repression of Gnrhr promoter activity. Further experiments strongly suggested that recruitment of AP1 and ER $\alpha$ to CREB binding protein (CBP) was mutually exclusive leading to inhibition of AP1-stimulated promoter activity by $\mathrm{E}_{2}$.

\section{IN VIVO ANALYSIS OF THE MOUSE, OVINE, AND RAT PROMOTERS IN TRANSGENIC MICE}

Since in vitro studies of promoter functions often suffer from limitation of the cellular models used in transient transfection analyses, the next and complementary approach consists in analyzing promoter activity in an in vivo context through the generation of transgenic mice.

Several studies have been published that use this procedure. The initial study by McCue et al. (1997) demonstrated the homologous up-regulation of Gnrhr promoter activity by GnRH. A 1900bp fragment corresponding the mouse Gnrhr promoter fused to the luciferase reporter gene has been microinjected in mouse embryos and mice harboring the transgene were selected. Analysis of luciferase activity in various tissues showed that the fusion gene was expressed essentially in the pituitary gland, to a 10-fold lower level in the brain and to a limited extend in the testis. These data are in agreement with those deduced from autoradiographic studies using ${ }^{125} \mathrm{I}$-labeled $\mathrm{GnRH}$ or in situ hybridization (Jennes et al., 1988, 1995; Leblanc et al., 1988; Ban et al., 1990; see review in Jennes et al., 1997). Surprisingly, the expression of the transgene was not detected in the ovary contrasting with a number of studies reporting the presence of GnRHR in this tissue, specifically 
in granulosa cells of atretic follicles. Using an antibody directed against GnRH, the authors further showed a decrease in transgene expression in the pituitary gland but not in the brain or testis. The GnRH antibody inhibitory action could be reversed by a GnRH agonist treatment. As expected from in vitro studies, the 1900-bp promoter contains essential GnRH response elements. However, $E_{2}$ treatment of these transgenic mice did not alter the activity of the transgene. This diverges with a number of reports demonstrating that, in vivo, $\mathrm{E}_{2}$ increases GnRHR number and steady-state level of Gnrhr mRNA in the pituitary (Hamernik et al., 1995; Turzillo et al., 1995; Kirkpatrick et al., 1998).

The same group has thus reinvestigated this regulation with novel lines of transgenic mice harboring a fusion construct containing the ovine receptor gene promoter linked to the luciferase reporter gene (Duval et al., 2000). Using either a 9.1 or a $2.7 \mathrm{~kb}$ promoter, they first showed that the ovine transgene displayed the same tissue-specific expression as the mouse promoter. The ovine transgene was indeed consistently expressed in the pituitary, brain, and gonads across the three analyzed transgenic lines. Pituitary expression was higher in females than in males whereas ovarian expression was significantly lower than the testicular one. In agreement with results obtained with the mouse promoter, immunoneutralization of GnRH reduced pituitary-specific expression of the luciferase reporter gene in ovariectomized mice, expression that could be restored by $\mathrm{E}_{2}$ treatment. Similar results were observed in castrated, male transgenic mice. Finally, combined treatments with $\mathrm{GnRH}$ agonist and $\mathrm{E}_{2}$ increased pituitary expression of the luciferase fusion gene to an extent greater than the sum of each individual treatment, suggesting synergistic activation of the ovine promoter.

The third study involving transgenic mice was different in at least two facets. Firstly, in this case, the reporter gene was the simian virus 40 (SV40) large $\mathrm{T}$ antigen and, secondly, the mouse promoter was the shortest used since it was 1.2-kb long only (Albarracin et al., 1999). With this fusion construct, the resulting heterozygote transgenic female mice were infertile preventing the generation of homozygote animals. Interestingly, all transgenic animals developed large intracranial tumors by $4-5$ months of age that were of pituitary origin. As evidenced by in situ hybridization, these tumors expressed the marker genes of the gonadotrope phenotype, i.e., GnRHR, glycoprotein hormone $\alpha$-subunit as well as FSH $\beta$ and LH $\beta$ subunits. The large T antigen was also expressed in the pituitary tumors but neither in the gonads or in the brain. This may indicate that the $1.2-\mathrm{kb}$, as compared with the $1.9-\mathrm{kb}$ promoter fragment, is not able to direct transgene expression to sites other than the pituitary, notably brain and gonads. Surprisingly, the expression of the SV40 large T antigen transgene driven by the GnRHR gene promoter results in female-specific infertility due to disruption of gonadotropin production and secretion even before tumor development (Jeong et al., 2009).

In our laboratory, the $3.2 \mathrm{~kb}$ rat promoter was placed upstream of the human placental alkaline phosphatase reporter gene (ALPP) and inserted into the mouse genome. The resulting transgenic mice expressed the ALPP exclusively in gonadotropes within the pituitary gland (Granger et al., 2004). Transgene expression was detected within the developing pituitary at E13.5 in some of the cells that also expressed the Cga. It showed that Gnrhr is the earliest marker of gonadotrope cell differentiation, before SF1 that is detected at E14.5. At E15.5, ALPP expression was localized in LHX3- and ISL1-immunoreactive positive cells in agreement with in vitro data showing that these LIM-HD proteins are involved in rat and mouse promoter activity. Importantly, the $3.2 \mathrm{~kb}$ promoter was also able to direct ALPP expression to several brain areas, in particular the hippocampus and the lateral septum, in agreement with previous data (Jennes et al., 1988, 1995; Leblanc et al., 1988; Ban et al., 1990; see review in Jennes et al., 1997). In contrast with the pituitary gland, transgene activity in the hippocampus was detected only after birth, increasing gradually until 14-20 days after birth and then remaining at constant level until 60 days after birth (Schang et al., 2011b). This occurred simultaneously in fibers extending from the hippocampus to the lateral septum, suggesting that GnRHR may be involved in post-natal maturation of the septo-hippocampal system. The same time-course was observed by measuring Gnrhr mRNA in rat hippocampus by quantitative RT-PCR, indicating that transgene expression directed by the rat promoter recapitulates rat endogenous Gnrhr expression in a mouse context. Further experiments using transient transfection of Gnrhr promoter luciferase fusion constructs in primary culture of rat hippocampus cell revealed that a RE1-silencing transcription factor (REST also known as NRSF)-like element located at $-2.5 \mathrm{~kb}$ may be involved in the inhibition of Gnrhr gene expression before birth. Finally, GnRH treatment of rat hippocampus primary cell culture led to stimulation of several markers of neurogenesis such as EGR1, synaptophysin, and spinophilin. Using this transgenic mouse model, several additional sites of transgene expression were detected, notably in the oculomotor pathway (Schang et al., 2011a). Interestingly, transgene expression was also detected in two functionally and evolutionary related organs, the pineal gland and the retina. Again, the onset of transgene expression was specific to these tissues, being detected at E13.5 and E17.5 in the pineal gland and retina, respectively (Schang et al., 2012a). In the pineal gland, transgene expression persisted until adulthood whereas it strongly decreased in the retina. During development, transgene expression was the strongest in the neuroblast cell layer of the retina and less marked in the ganglion cell layer. In the pineal gland, transgene expression was constantly observed in approximately $50 \%$ of the cells whatever the developmental stage. Finally, transgene expression was strongly detected in the testes of transgenic mice in some Leydig cells (Schang et al., 2011a).

Recent studies involving functional genomic approaches have shown that regulatory domains may be located within the gene locus at several kilobases, either $5^{\prime}$ upstream or $3^{\prime}$ downstream as well as within intronic regions. This is well demonstrated particularly for genes coding for transcription factors, notably SF1 (Shima etal., 2012 and references therein), or genes encoding for factors involved in early developmental processes such as the LIM-HD proteins LHX3 and ISL1 (Kappen and Salbaum, 2009; Mullen et al., 2012). Conversely, other studies have shown that the most important genetic regulation may be contained within only $1 \mathrm{~kb} 5^{\prime}$ upstream of the transcription start site, including informations regarding epigenetic modifications such as pattern of DNA methylation (Lienert et al., 2011). Furthermore, species-specific informations would be encoded into DNA sequence and appears to prevail over species-specific cellular environment. A human 
chromosome introduced into a mouse cell line directs genetic and epigenetic modifications as it does in a human cell context and thus differently from its mouse counterpart (Wilson et al., 2008). Therefore, data obtained using transgenic mice as well as those described above must be considered bearing in mind the fact that all regulatory sequences are not necessarily contained within the $5^{\prime}$ upstream region of the gene only, even if relatively short $5^{\prime}$ upstream sequences may contain master regulatory informations. This could explain why the human GNRHR promoter responded negatively while mouse or rat promoters are stimulated by GnRH.

To overcome these limitations, a double knock-in mice model was recently developed. In this binary genetic approach, the Crerecombinase was inserted into the Gnrhr locus whereas the YFP reporter gene, preceded by a floxed stop signal, was inserted into the ubiquitously expressed ROSA26 locus. The Cre-mediated excision of the stop signal led to a constitutive YFP expression in about $15 \%$ of the cells in the male anterior pituitary. Furthermore, the fluorescent signal was only colocalized with $\mathrm{LH} \beta$ and/or FSH $\beta$ subunits as demonstrated by immunohistochemistry. These YFP mice have allowed single-cell analysis on living cells which have revealed unexpected heterogeneity in the resting properties of gonadotrope cells as well as in their secretory, electrophysiological, and calcium responses to $\mathrm{GnRH}$ (Wen et al., 2008).

\section{SF1, A PAN-SPECIES TRANSCRIPTION FACTOR CRITICAL FOR GONADOTROPE-SPECIFIC EXPRESSION}

An obvious conclusion that emerges from this overview of the mechanisms involved in Gnrhr expression is the important role of the orphan nuclear receptor SF1. It is undoubtedly involved in the tissue-specific expression of the human, mouse, and rat GnRHR. It is also likely involved in the tissue-specific expression of the ovine gene since the promoter is strongly homologous to its human counterpart. SF1 is crucial not only for tissue-specific expression but also for the regulation by extracellular signals as evidenced by PACAP and PKA-dependent regulations of the rat promoter. This may be related to the other important functions of SF1 in the tissue-specific and regulated expression of Cga and Lhb genes, two other markers of the gonadotrope lineage. Consistent with these data, the SF1 knockout mice exhibit impaired expression of $\mathrm{LH} \beta, \mathrm{FSH} \beta$, and GnRHR in pituitary gonadotropes in addition to other major defects such as agenesis of the ventro-medial hypothalamus, complete adrenal and gonadal agenesis and maleto-female sex reversal with persistence of Müllerian structures in male (Ingraham et al., 1994; Ikeda et al., 1995; Luo et al., 1995). To bypass the influence of hypothalamic deficiencies inherent to this transgenic model, SF1 has been inactivated specifically in the anterior pituitary using the Cre-loxP system (Zhao et al., 2001). These pituitary-specific SF1 knockout mice are sterile and never mature sexually. Consistent with a direct role of SF1 at the pituitary level, FSH and LH are markedly decreased in the pituitary-specific SF1 knockout mice as well as are gonadotropin $\beta$-subunit and Gnrhr mRNAs as assessed by semi-quantitative RT-PCR.

The important role of SF1 has been further confirmed in humans by the discovery of a heterozygous missense mutation in the DNA binding domain of SF1 in a patient with complete sex reversal, testicular dysgenesis, and adrenal failure (Achermann et al., 1999). However, this patient displayed a relative preservation of gonadotrope function. This may be due either to its heterozygous genotype or to a relative autonomy of the gonadotrope function with respect to SF1. In agreement with the latest hypothesis, GnRH treatment can restore LH and FSH secretion in SF1 knockout mice (Ikeda etal., 1995), suggesting that SF1 is not required for the emergence and maintenance of gonadotrope function. Furthermore, some tissues known to express GnRHR such as amygdala and hippocampus are deprived of SF1 (Schang et al., 2011b). This suggests that other factor(s) than SF1 are needed for the tissue-specific transcriptional onset of the Gnrhr. To identify this (or these) factor(s), several parameters must be considered. From an ontogenetic point of view, the date of appearance of the Gnrhr transcripts must be correlated with the presence of the factor in the fetal pituitary or in fetal tissues that will express the GnRHR in the adult. For instance, binding sites for GnRH have been detected as early as 12-13 days of gestation in the rat developing pituitary and GnRHR mRNA at 14.5 and 15.5 days post-conception in testis and ovary from rat fetuses (Aubert et al., 1985; Jennes, 1990; Botté et al., 1998). This factor should also be able to activate the promoter of the Gnrhr in an SF1-independent manner in transient transfection assays.

\section{CONCLUSIONS AND PERSPECTIVES}

An increasing number of studies on gene regulations and promoter activities aim to demonstrate the existence of specific regulatory units that bring together several response elements. From one tissue to another, the same elements may bind different factors resulting in tissue- or cell-specific modulations of gene expression. This ability to bind different factors is likely facilitated by sequence degeneracy of the response elements that lie within these regulatory units. Consequently, the degenerated response elements may be less efficient than their canonical counterparts when they are isolated from their promoter context. Efficiency is recovered in the original promoter context through synergistic interactions with other transcription factors belonging to the regulatory unit. Interestingly, this synergy may be attenuated if the wild-type degenerated element is artificially replaced by its canonical counterpart (Ito et al., 2000). In the Gnrhr promoters, several elements display such characteristics. In particular, the SF1 binding site and the proximal CRE in the rat and mouse promoter differ from the consensus sequence (TGACGTTT instead of TGACGTCA for the later). In gel-shift experiment, both the SF1 element and the CRE display an apparent weaker affinity for their cognate transcription factors than the SF1 binding site from the rat aromatase gene or the canonical CRE sequence (Pincas et al., 2001a,b). PACAP- and PKA-dependent regulations of the rat promoter are mediated by these two elements that may thus be considered as a cAMP regulatory unit (Roesler, 2000). The SURG-1 and SURG-2 elements establish another functional regulatory unit since they are both required for the GnRH up-regulation of the mouse promoter. The distal GnSE together with the proximal domain containing the SF1 binding site also form a regulatory unit for the tissuespecific activity of the rat promoter. Different regulatory units may also bind different combinations of factors depending on the tissue or the cell type that expresses the Gnrhr. We have recently demonstrated that OTX2 interacted with two distinct partners depending on the cell context (Schang et al., 2012a). 
In a gonadotrope cell context, OTX2 interacted with PROP1 on two adjacent response elements located between -388 and -357 , each of them encompassing a core TAAT motif. In a neutral cell context, OTX2 acted in synergy with CREB and formed a regulatory unit that involved CRE, an AP1 response element together with a new OTX2 binding site containing a TAAT core motif located at $-163 /-160$. This motif is thus located $50 \mathrm{bp}$ upstream of the CRE and 180 bp downstream of the AP1 element establishing a regulatory unit extending over $200 \mathrm{bp}$ within the proximal promoter, markedly larger than the PROP1/OTX2 regulatory unit (Schang et al., 2012a). Whether such difference in size of these regulatory units as well as the other cited above is functionally relevant remains to be determined. In this respect, an important point that must be considered is the chromatin structure that depends on epigenetic modifications. At least, two histone $\mathrm{H} 3$ modifications are predominantly involved in transcriptional regulation: tri-methylation of Lys 4 of histone H3 (H3K4me3) and tri-methylation of Lys 27 of histone H3 (H3K27me3; see review in Greer and Shi, 2012). They are linked to gene activity and gene silencing, respectively. $\mathrm{H} 3 \mathrm{~K} 4 \mathrm{me} 3$ is catalyzed by trithorax group (trxG) proteins, whereas H3K27me3 is catalyzed by polycomb-group (PcG) proteins (Schuettengruber et al., 2007; Ku etal., 2008). PcG proteins reside in two main complexes, termed Polycomb repressive complexes 1 and 2 (PRC1 and PRC2). PRC2 catalyzes H3K27me3 and components of PRC1 are recruited to the modified histone leading to ubiquitinylation of histone $\mathrm{H} 2 \mathrm{~A}$ at lysine 119 which in turn prohibits RNA polymerase II elongation (Simon and Kingston, 2009). This results in stable transcriptional repression. Analysis of H3K4me3 and H3K27me3 modifications by ChIP assay showed that in gonadotrope cell lines, the Gnrhr promoter preferentially displayed the active mark whereas in lactosomatotrope or corticotrope cell lines, it displayed preferentially the repressive mark

\section{REFERENCES}

Achermann, J. C., Ito, M., Ito, M. Hindmarsh, P. C., and Jameson, J. L. (1999). A mutation in the gene encoding steroidogenic factor1 causes XY sex reversal and adrenal failure in humans. Nat. Genet. 22, 125-126.

Achermann, J. C., Weiss, J., Lee, E. J., and Jameson, J. L. (2001). Inherited disorders of the gonadotropin hormones. Mol. Cell. Endocrinol. 179, 89-96.

Alarid, E. T., Windle, J. J., Whyte, D. B., and Mellon, P. L. (1996). Immortalization of pituitary cells at discrete stages of development by directed oncogenesis in transgenic mice. Development 122, 3319-3329.

Albarracin, C. T., Frosch, M. P., and Chin, W. W. (1999). The gonadotropin-releasing hormone receptor gene promoter directs pituitary-specific oncogene expression in transgenic mice. Endocrinology 140, 2415-2421.

Albarracin, C. T., Kaiser, U. B., and Chin, W. W. (1994). Isolation and characterization of the $5^{\prime}$-flanking region of the mouse gonadotropinreleasing hormone receptor gene. Endocrinology 135, 2300-2306.

Anderson, L. (1996). Intracellular mechanisms triggering gonadotrophin secretion. Rev. Reprod. 1, 193-202.

Aubert, M. L., Begeot, M., Winiger, B. P., Morel, G., Sizonenko, P. C., and Dubois, P. M. (1985). Ontogeny of hypothalamic luteinizing hormonereleasing hormone ( $\mathrm{GnRH}$ ) and pituitary GnRHRs in fetal and neonata rats. Endocrinology 116, 1565-1576.

Bachir, L. K., Garrel, G., Lozach, A., Laverrière, J. N., and Counis, R. (2003). The rat pituitary promoter of the neuronal nitric oxide synthase gene contains an Sp1, LIM homeodomain-dependent enhancer and a distinct bipartite gonadotropin-releasing hormoneresponsive region. Endocrinology 144, 3995-4007.

Bachir, L. K., Laverrière, J. N., and Counis, R. (2001). Isolation

(unpublished data). This is well correlated with Gnrhr mRNA levels that are not detected in lactosomatotrope and corticotrope cell lines. Constitutive Gnrhr transcription is thus likely controlled by mechanisms involving trxG proteins in gonadotrope cells whereas in other pituitary cells, PcG proteins stably repress Gnrhr expression. In mammals, composition of trxG and PcG protein complexes displays broad diversity depending on the considered family of genes. A critical point would be to determine what are the main actors involved in histone methyltransferase and demethylase activity regarding the Gnrhr. Furthermore, PcG complexes are known to be clustered into subnuclear structures that look like nuclear foci termed polycomb bodies (Pirrotta and $\mathrm{Li}, 2012$ ). Conversely, active genes are preferentially located in different subnuclear structures referred to as transcription factories that contain active RNA polymerase II or interchromatin granule clusters (also termed nuclear speckles) that contain histone-modifying enzymes, transcription elongation factors, and splicing machinery (Meldi and Brickner, 2011; Spector and Lamond, 2011). In the developing pituitary gland, lineage specification likely requires relocation of marker genes like the Gnrhr into these subnuclear structures (Yang et al., 2011). The elucidation of the mechanisms underlying this reorganization would permit to shed new light on Gnrhr expression, on gonadotrope cell lineage specification and differentiation, and more generally on organ development.

\section{ACKNOWLEDGMENTS}

This study was supported by grants from the Centre National de la Recherche Scientifique, the Paris 7 University, and the Agence Nationale pour la Recherche (ANR-08-CES-011-03). Anne-Laure Schang is supported by a fellowship from the Ministère de l'Education Nationale, de la Recherche et de la Technologie (MENRT).

and characterization of a rat nitric oxide synthase type I gene promoter that confers expression and regulation in pituitary gonadotrope cells. Endocrinology 142, 4631-4642.

Ban, E., Crumeyrolle-Arias, M., Latouche, J., Leblanc, P., Heurtier, J. F., Drieu, K., etal. (1990). GnRHRs in rat brain, pituitary and testis; modulation following surgical and gonadotropin-releasing hormone agonist-induced castration. Mol. Cell. Endocrinol. 70, 99-107.

Bliss, S. P., Miller, A., Navratil, A. M., Xie, J., McDonough, S. P., Fisher, P. J., et al. (2009). ERK signaling in the pituitary is required for female but not male fertility. Mol. Endocrinol. 23, 1092-1101.

Bodner, M., Castrillo, J. L, Theill, L. E., Deerinck, T., Ellisman, M., and Karin, M. (1988). The pituitaryspecific transcription factor GHF- 1 is a homeobox-containing protein. Cell 55, 505-518.

Botté, M. C., Chamagne, A. M., Carre, M. C., Counis, R., and Kottler, M.
L. (1998). Fetal expression of GnRH and Gnrhrs in rat testis and ovary. J. Endocrinol. 159, 179-189.

Braden, T. D., and Conn, P. M. (1992). Activin-A stimulates the synthesis of gonadotropin-releasing hormone receptors. Endocrinology 130, 21012105.

Brown, P., and McNeilly, A. S. (1999). Transcriptional regulation of pituitary gonadotrophin subunit genes. Rev. Reprod. 4, 117-124.

Cheng, C. K., and Leung, P. C. (2005). Molecular biology of gonadotropinreleasing hormone (GnRH)-I, GnRH-II, and their receptors in humans. Endocr. Rev. 26, 283-306.

Cheng, C. K., Chow, B. K., and Leung, P. C. (2003). An activator protein 1-like motif mediates $17 \beta$-estradiol repression of gonadotropin-releasing hormone receptor promoter via an estrogen receptor alpha-dependent mechanism in ovarian and breast cancer cells. Mol. Endocrinol. 17, 2613-2629. Cheng, C. K., Yeung, C. M., Chow, B. K., and Leung, P. C. (2002a). 
Characterization of a new upstream GnRH receptor promoter in human ovarian granulosa-luteal cells. Mol. Endocrinol. 16, 1552-1564.

Cheng, C. K., Yeung, C. M., Hoo, R. L., Chow, B. K., and Leung, P. C. (2002b). Oct-1 is involved in the transcriptional repression of the gonadotropin-releasing hormone receptor gene. Endocrinology 143, 4693-4701.

Cheng, K. W., and Leung, P. C. (2001). Human gonadotropin-releasing hormone receptor gene transcription: up-regulation by $3^{\prime}, 5^{\prime}$-cyclic adenosine monophosphate/protein kinase A pathway. Mol. Cell. Endocrinol. 181, 15-26.

Cheng, K. W., Chow, B. K., and Leung, P. C. (2001a). Functional mapping of a placenta-specific upstream promoter for human gonadotropin-releasing hormone receptor gene. Endocrinology 142, 1506-1516.

Cheng, K. W., Cheng, C. K., and Leung, P. C. (2001b). Differential role of PR-A and -B isoforms in transcription regulation of human Gnrhr. Mol. Endocrinol. 15, 2078-2092.

Cheng, K. W., Ngan, E. S., Kang, S. K., Chow, B. K., and Leung, P. C. (2000). Transcriptional down-regulation of human gonadotropin-releasing hormone $(\mathrm{GnRH})$ receptor gene by $\mathrm{GnRH}$ : role of protein kinase $\mathrm{C}$ and activating protein 1. Endocrinology 141, 3611-3622.

Cherrington, B. D., Bailey, J. S., Diaz, A. L., and Mellon, P. L. (2008). NeuroD1 and Mash1 temporally regulate $\mathrm{GnRH}$ receptor gene expression in immortalized mouse gonadotrope cells. Mol. Cell. Endocrinol. 295, 106-114.

Cherrington, B. D., Farmerie, T. A., and Clay, C. M. (2006). A specific helical orientation underlies the functional contribution of the activin responsive unit to transcriptional activity of the murine gonadotropin-releasing hormone receptor gene promoter. Endocrine 29, 425-433.

Cherrington, B. D., Farmerie, T. A., Lents, C. A., Cantlon, J. D., Roberson, M. S., and Clay, C. M. (2005). Activin responsiveness of the murine gonadotropin-releasing hormone receptor gene is mediated by a composite enhancer containing spatially distinct regulatory elements. Mol. Endocrinol. 19, 898-912.

Chevrier, L., Guimiot, F., and de Roux, N. (2011). GnRH receptor mutations in isolated gonadotropic deficiency. Mol. Cell. Endocrinol. 346, 21-28.

Clay, C. M., Nelson, S. E., Digregorio, G. B., Campion, C. E., Wiedemann, A. L., and Nett, R. J.
(1995). Cell-specific expression of the mouse gonadotropin-releasing hormone $(\mathrm{GnRH})$ receptor gene is conferred by elements residing within 500 bp of proximal $5^{\prime}$ flanking region. Endocrine 3, 615-622.

Connor, E. E., Ashwell, M. S., Kappes, S. M., and Dahl, G. E. (1999). Mapping of the bovine growth hormonereleasing hormone receptor $(\mathrm{GHRH}-$ $\mathrm{R})$ gene to chromosome 4 by linkage analysis using a novel PCR-RFLP. $J$. Anim. Sci. 77, 793-794.

de Roux, N., and Milgrom, E. (2001). Inherited disorders of $\mathrm{GnRH}$ and gonadotropin receptors. Mol. Cell. Endocrinol. 179, 83-87.

de Roux, N., Young, J., Misrahi, M., Genet, R., Chanson, P., Schaison, G., et al. (1997). A family with hypogonadotropic hypogonadism and mutations in the gonadotropin-releasing hormone receptor. N. Engl. J. Med. 337, 15971602.

Delahaye, R., Manna, P. R., Berault, A., Berreur-Bonnenfant, J., Berreur, P., and Counis R. (1997). Rat gonadotropin-releasing hormone receptor expressed in insect cells induces activation of adenylyl cyclase. Mol. Cell. Endocrinol. 135, 119-127.

Drouin, J., Lamolet, B., Lamonerie, T., Lanctôt, C., and Tremblay, J. J. (1998). The PTX family of homeodomain transcription factors during pituitary developments. Mol. Cell. Endocrinol. 140, 31-36.

Duan, W. R., Ito, M., Park, Y., Maizels, E. T., Hunzicker-Dunn, M., and Jameson, J. L. (2002). GnRH regulates early growth response protein 1 transcription through multiple promoter elements. Mol. Endocrinol. 16, 221-233.

Duval, D. L., Ellsworth, B. S., and Clay, C. M. (1999). Is gonadotrope expression of the gonadotropin releasing hormone receptor gene mediated by autocrine/paracrine stimulation of an activin response element? Endocrinology 140, 19491952.

Duval, D. L., Farris, A. R., Quirk, C. C., Nett, T. M., Hamernik, D. L., and Clay C. M. (2000). Responsiveness of the ovine gonadotropinreleasing hormone receptor gene to estradiol and gonadotropin-releasing hormone is not detectable in vitro but is revealed in transgenic mice. Endocrinology 141, 1001-1010.

Duval, D. L., Nelson, S. E., and Clay, C. M. (1997a). A binding site for steroidogenic factor-1 is part of a complex enhancer that mediates expression of the murine gonadotropin-releasing hormone receptor gene. Biol. Reprod. 56, 160-168.

Duval, D. L., Nelson, S. E., and Clay, C. M. (1997b). The tripartite basal enhancer of the gonadotropinreleasing hormone $(\mathrm{GnRH})$ receptor gene promoter regulates cell-specific expression through a novel GnRHR activating sequence. Mol. Endocrinol. 11, 1814-1821.

Ellsworth, B. S., Burns, A. T., Escudero, K. W., Duval, D. L., Nelson, S. E., and Clay, C. M. (2003a). The gonadotropin releasing hormone (GnRH) receptor activating sequence (GRAS) is a composite regulatory element that interacts with multiple classes of transcription factors including Smads, AP-1 and a forkhead DNA binding protein. Mol. Cell. Endocrinol. 206, 93-111.

Ellsworth, B. S., White, B. R., Burns, A. T., Cherrington, B. D., Otis, A. M., and Clay, C. M. (2003b). c-JunN-terminal kinase activation of activator protein-1 underlies homologous regulation of the gonadotropin-releasing hormone receptor gene in alpha T3-1cells. Endocrinology 144, 839-849.

Ericson, J., Norlin, S., Jessell, T. M. and Edlund, T. (1998). Integrated FGF and BMP signaling controls the progression of progenitor cell differentiation and the emergence of pattern in the embryonic anterior pituitary. Development 125, 1005 1015.

Fan, N. C., Jeung, E. B., Peng, C., Olofsson, J. I., Krisinger, J., and Leung, P. C. (1994). The human gonadotropinreleasing hormone $(\mathrm{GnRH})$ receptor gene: cloning, genomic organization and chromosomal assignment. $\mathrm{Mol}$. Cell. Endocrinol. 103, R1-R6.

Fan, N. C., Peng, C., Krisinger, J., and Leung, P. C. (1995). The human gonadotropin-releasing hormone receptor gene: complete structure including multiple promoters, transcription initiation sites, and polyadenylation signals. Mol. Cell. Endocrinol. 107, R1-R8.

Fernandez-Vazquez, G., Kaiser, U. B., Albarracin, C. T., and Chin, W. W. (1996). Transcriptional activation of the gonadotropin-releasing hormone receptor gene by activin A. Mol. Endocrinol. 10, 356-366.

Garrel, G., Delahaye, R., Hemmings, B. A., and Counis, R. (1995). Modulation of regulatory and catalytic subunit levels of cAMP-dependent protein kinase $\mathrm{A}$ in anterior pituitary cells in response to direct activation of protein kinases $\mathrm{A}$ and $\mathrm{C}$ or after GnRH stimulation. Neuroendocrinology 62, 514-522.
Garrel, G., Lerrant, Y., Siriostis, C., Berault, A., Magre, S., Bouchaud, C., etal. (1998). Evidence that gonadotropin-releasing hormone stimulates gene expression and levels of active nitric oxide synthase type I in pituitary gonadotrophs, a process altered by desensitization and, indirectly, by gonadal steroids. Endocrinology 139, 2163-2170.

Garrel, G., McArdle, C. A., Hemmings, B. A., and Counis, R. (1997). Gonadotropin-releasing hormone and pituitary adenylate cyclase-activating polypeptide affect levels of cyclic adenosine $3^{\prime}, 5^{\prime}$ monophosphate-dependent protein kinase A (PKA) subunits in the clonal gonadotrope alphaT3-1 cells: evidence for cross-talk between PKA and protein kinase $C$ pathways. Endocrinology 138, 2259-2266.

Garrel, G., Simon, V., Thieulant, M. L., Cayla, X., Garcia, A., Counis, R., etal. (2010). Sustained gonadotropin-releasing hormone stimulation mobilizes the cAMP/PKA pathway to induce nitric oxide synthase type 1 expression in rat pituitary cells in vitro and in vivo at proestrus. Biol. Reprod. 82, 1170-1179.

Granger, A., Bleux, C., Kottler, M. L., Rhodes, S. J., Counis, R., and Laverrière, J. N. (2006). The LIM-homeodomain proteins Isl-1 and Lhx3 act with steroidogenic factor 1 to enhance gonadotropespecific activity of the gonadotropinreleasing hormone receptor gene promoter. Mol. Endocrinol. 20, 20932108.

Granger, A., Ngô-Muller, V., Bleux, C., Guigon, C., Pincas, H., Magre, S., et al. (2004). The promoter of the rat gonadotropin-releasing hormone receptor gene directs the expression of the human placental alkaline phosphatase reporter gene in gonadotrope cells in the anterior pituitary gland as well as in multiple extrapituitary tissues. Endocrinology 145, 983-993.

Greer, E. L., and Shi, Y. (2012). Histone methylation: a dynamic mark in health, disease and inheritance. Nat. Rev. Genet. 13, 343-357.

Hamernik, D. L., Clay, C. M., Turzillo, A., Van Kirk, E. A., and Moss, G. E. (1995). Estradiol increases amounts of messenger ribonucleic acid for gonadotropin-releasing hormone receptors in sheep. Biol. Reprod. 53, 179-185.

Han, X. B., and Conn, P. M. (1999). The role of protein kinases $A$ and $\mathrm{C}$ pathways in the regulation of mitogen-activated protein 
kinase activation in response to gonadotropin-releasing hormone receptor activation. Endocrinology 140, 2241-2251.

Hapgood, J. P., Sadie, H., van Biljon, W., and Ronacher, K. (2005). Regulation of expression of mammalian gonadotrophin-releasing hormone receptor genes. J. Neuroendocrinol. 17, 619-638.

Hoo, R. L., Ngan, E. S., Leung, P. C., and Chow, B. K. (2003). Two Inr elements are important for mediating the activity of the proximal promoter of the human gonadotropin-releasing hormone receptor gene. Endocrinology 144, 518-527.

Ikeda, Y., Luo, X., Abbud, R., Nilson, J. H., and Parker, K. L. (1995). The nuclear receptor steroidogenic factor 1 is essential for the formation of the ventromedial hypothalamic nucleus. Mol. Endocrinol. 9, 478-486.

Ingraham, H. A., Chen, R. P., Mangalam, H. J., Elsholtz, H. P., Flynn, S. E., Lin, C. R., et al. (1988). A tissue-specific transcription factor containing a homeodomain specifies a pituitary phenotype. Cell 55 , 519-529.

Ingraham, H. A., Lala, D. S., Ikeda, Y., Luo, X., Shen, W. H., Nachtigal, M. W., et al. (1994). The nuclear receptor steroidogenic factor 1 acts at multiple levels of the reproductive axis. Genes Dev. 8, 2302-2312.

Ito, M., Park, Y., Weck, J., Mayo, K. E., and Jameson, J. L. (2000). Synergistic activation of the inhibin alpha-promoter by steroidogenic factor-1 and cyclic adenosine $3^{\prime}, 5^{\prime}$ monophosphate. Mol. Endocrinol. 14, 66-81.

Janovick, J. A., and Conn, P. M. (1994). Gonadotropin-releasing hormone (GnRH)-receptor coupling to inositol phosphate and prolactin production in GH3 cells stably transfected with rat GnRHR complementary deoxyribonucleic acid. Endocrinology 135, 2214-2219.

Japón, M.A., Rubinstein, M., Low, M. J. (1994). In situ hybridization analysis of anterior pituitary hormone gene expression during fetal mouse development. J. Histochem. Cytochem. 42, 1117-1125.

Jennes, L. (1990). Prenatal development of gonadotropin-releasing hormone receptors in the rat anterior pituitary. Endocrinology 126, 942-947.

Jennes, L., Brame, B., Centers, A., Janovick, J. A., and Conn, P. M. (1995). Regulation of hippocampal gonadotropin releasing hormone $(\mathrm{GnRH})$ receptor mRNA and GnRH-stimulated inositol phosphate production by gonadal steroid hormones. Brain Res. Mol. Brain Res. 33, 104-110.

Jennes, L., Dalati, B., and Conn, P. M. (1988). Distribution of gonadrotropin releasing hormone agonist binding sites in the rat central nervous system. Brain Res. 452, 156-164.

Jennes, L., Eyigor, O., Janovick, J. A., and Conn, P. M. (1997). Brain gonadotropin releasing hormone receptors: localization and regulation. Recent Prog. Horm. Res. 52, 475-490.

Jeong, K. H., Chin, W. W., and Kaiser, U. B. (2004). Essential role of the homeodomain for pituitary homeobox 1 activation of mouse gonadotropinreleasing hormone receptor gene expression through interactions with c-Jun and DNA. Mol. Cell. Biol. 24, 6127-6139.

Jeong, K. H., Gill, J. C., Nosé, V., Parlow, A. F., Carroll, R. S., and Kaiser, U. B. (2009). Expression of a gonadotropin-releasing hormone receptor-simian virus $40 \mathrm{~T}$-antigen transgene has sex-specific effects on the reproductive axis. Endocrinology 150, 3383-3391.

Jiang, Z., Gibson, J. P., Archibald, A. L., and Haley, C. S. (2001). The porcine gonadotropin-releasing hormone receptor gene (GNRHR): genomic organization, polymorphisms, and association with the number of corpora lutea. Genome 44 7-12.

Kaiser, U. B., Dushkin, H., Altherr, M. R., Beier, D. R., and Chin, W. W. (1994). Chromosomal localization of the gonadotropin-releasing hormone receptor gene to human chromosome 4q13.1-q21.1 and mouse chromosome 5. Genomics 20, 506-508.

Kaiser, U. B., Katzenellenbogen, R. A., Conn, P. M., and Chin, W. W. (1994). Evidence that signalling pathways by which thyrotropin-releasing hormone and gonadotropin-releasing hormone act are both common and distinct. Mol. Endocrinol. 8, 1038 1048.

Kakar, S. S. (1997). Molecular structure of the human gonadotropinreleasing hormone receptor gene. Eur. J. Endocrinol. 137, 183-192.

Kakar, S. S., and Neill, J. D. (1995). The human gonadotropin-releasing hormone receptor gene (GNRHR) maps to chromosome band $4 \mathrm{q} 13$. Cytogenet. Cell Genet. 70, 211-214.

Kakar, S. S., Winters, S. J., Zacharias, W., Miller, D. M., and Flynn, S. (2003). Identification of distinct gene expression profiles associated with treatment of LbetaT2 cells with gonadotropin-releasing hormone agonist using microarray analysis. Gene 308, 67-77.

Kam, K. Y., Jeong, K. H., Norwitz, E. R., Jorgensen, E. M., and Kaiser, U. B. (2005). Oct-1 and nuclear factor Y bind to the SURG-1 element to direct basal and gonadotropin-releasing hormone ( $\mathrm{GnRH})$-stimulated mouse $\mathrm{GnRH}$ receptor gene transcription. Mol. Endocrinol. 19, 148-162.

Kang, S. K., Cheng, K. W., Ngan, E. S., Chow, B. K., Choi, K. C. and Leung, P. C. (2000). Differential expression of human gonadotropinreleasing hormone receptor gene in pituitary and ovarian cells. Mol. Cell. Endocrinol. 162, 157-166.

Kappen, C., and Salbaum, J. M. (2009). Identification of regulatory element in the Isll gene locus. Int. J. Dev. Biol. 53, 935-946.

Kawaminami, M., Etoh, S., Miyaoka, H., Sakai, M., Nishida, M., Kurusu, S., et al. (2002). Annexin 5 messenger ribonucleic acid expression in pituitary gonadotropes is induced by gonadotropin-releasing hormone (GnRH) and modulates GnRH stimulation of gonadotropin release. $\mathrm{Neu}$ roendocrinology 75, 2-11.

Kirkpatrick, B. L., Esquivel E., Moss, G. E., Hamernik, D. L., and Wise, M. E. (1998). Estradiol and gonadotropinreleasing hormone $(\mathrm{GnRH})$ interact to increase $\mathrm{GnRH}$ receptor expression in ovariectomized ewes after hypothalamic-pituitary disconnection. Endocrine 8, 225-229.

Kottler, M. L., Lorenzo, F., Bergametti, F., Commercon, P., Souchier, C., and Counis, R. (1995). Subregional mapping of the human gonadotropin-releasing hormone receptor (GnRHR) gene to $4 \mathrm{q}$ between the markers D4S392 and D4S409. Hum. Genet. 96, 477-480.

Kraus, S., Naor, Z., and Seger, R. (2001). Intracellular signaling pathways mediated by the gonadotropinreleasing hormone $(\mathrm{GnRH})$ receptor. Arch. Med. Res. 32, 499-509.

Ku, M., Koche, R. P., Rheinbay, E., Mendenhall, E. M., Endoh, M., Mikkelsen, T. S. etal. (2008). Genomewide analysis of PRC1 and PRC2 occupancy identifies two classes of bivalent domains. PLoS Genet. 4:e1000242. doi: 10.1371/journal.pgen.1000242

Larivière, S., Garrel, G., Simon, V., Soh, J. W., Laverrière, J. N., Counis, R., et al. (2007). Gonadotropin-releasing hormone couples to $3^{\prime}, 5^{\prime}$-cyclic adenosine- $5^{\prime}$-monophosphate pathway through novel protein kinase $\mathrm{C} \delta$ and $-\epsilon$ in L $\beta$ T2 gonadotrope cells. Endocrinology 148 1099-1107.
Larivière, S., Garrel-Lazayres, G., Simon, V., Shintani, N., Baba, A., Counis, R., etal. (2008). Gonadotropin-releasing hormone inhibits pituitary adenylyl cyclase-activating polypeptide coupling to $3^{\prime}, 5^{\prime}$-cyclic adenosine$5^{\prime}$-monophosphate pathway in L $\beta \mathrm{T} 2$ gonadotrope cells through novel protein kinase $\mathrm{C}$ isoforms and phosphorylation of pituitary adenylyl cyclase-activating polypeptide type I receptor. Endocrinology 149, 6389-6398.

Layman, L. C., Cohen, D. P., Jin, M., Xie, J., Li, Z., Reindollar, R. H., et al. (1998). Mutations in gonadotropinreleasing hormone receptor gene cause hypogonadotropic hypogonadism. Nat. Genet. 18, 14-15.

Leblanc, P., Crumeyrolle, M., Latouche, J., Jordan, D., Fillion, G., L'Heritier, A., et al. (1988). Characterization and distribution of receptors for gonadotropin-releasing hormone in the rat hippocampus. Neuroendocrinology 48, 482-488.

Lents, C. A., Farmerie, T. A., Cherrington, B. D., and Clay, C. M. (2009). Multiple core homeodomain binding motifs differentially contribute to transcriptional activity of the murine gonadotropin-releasing hormone receptor gene promoter. Endocrine 35, 356-364.

Leung, P. C., Squire, J., Peng, C., Fan, N., Hayden, M. R., and Olofsson, J. I. (1995). Mapping of the gonadotropin-releasing hormone (GnRH) receptor gene to human chromosome $4 \mathrm{q} 21.2$ by fluorescence in situ hybridization. Mamm. Genome 6, 309-310.

Li, J., Liu, Q., Qiu, M., Pan, Y., Li, Y., and Shi, T. (2006). Identification and analysis of the mouse basic/helixloop-helix transcription factor family. Biochem. Biophys. Res. Commun. 350, 648-656.

Li, S., Crenshaw, E. B. III, Rawson, E. J., Simmons, D. M., Swanson, L. W., and Rosenfeld, M. G. (1990). Dwarf locus mutants lacking three pituitary cell types result from mutations in the POU-domain gene Pit-1. Nature 347, 528-533.

Lienert, F., Wirbelauer, C., Som, I., Dean, A., Mohn, F., and Schübeler, D. (2011). Identification of genetic elements that autonomously determine DNA methylation states. Nat. Genet. 43, 1091-1097.

Lin, X., and Conn, P. M. (1998). Transcriptional activation of gonadotropin-releasing hormone $(\mathrm{GnRH})$ receptor gene by $\mathrm{GnRH}$ and cyclic adenosine monophosphate. Endocrinology 139, 3896-3902. 
Lin, X., and Conn, P. M. (1999). Transcriptional activation of gonadotropin-releasing hormone (GnRH) receptor gene by $\mathrm{GnRH}$ : involvement of multiple signal transduction pathways. Endocrinology 140, 358-364.

Liu, F., Austin, D. A., Mellon, P. L., Olefsky, J. M., and Webster, N. J. (2002). GnRH activates ERK1/2 leading to the induction of $\mathrm{c}$-fos and $\mathrm{LH} \beta$ protein expression in L $\beta$ T2 cells. Mol. Endocrinol. 16, 419-434.

Lozach, A., Garrel, G., Lerrant, Y., Berault, A., and Counis, R. (1998). GnRH-dependent up-regulation of nitric oxide synthase I level in pituitary gonadotrophs mediates cGMP elevation during rat proestrus. $\mathrm{Mol}$. Cell. Endocrinol. 143, 43-51.

Luo, X., Ikeda, Y., Schlosser, D. A., and Parker, K. L. (1995). Steroidogenic factor 1 is the essential transcript of the mouse Ftz-F1 gene. Mol. Endocrinol. 9, 1233-1239.

Maya-Nunez, G., and Conn, P. M. (1999). Transcriptional regulation of the gonadotropin-releasing hormone receptor gene is mediated in part by a putative repressor element and by the cyclic adenosine $3^{\prime}, 5^{\prime}$-monophosphate response element. Endocrinology 140, $3452-$ 3458.

Maya-Nunez, G., and Conn, P. M. (2001). Cyclic adenosine $3^{\prime}, 5^{\prime}$ monophosphate (cAMP) and cAMP responsive element-binding protein are involved in the transcriptional regulation of gonadotropin-releasing hormone $(\mathrm{GnRH})$ receptor by $\mathrm{GnRH}$ and mitogen-activated protein kinase signal transduction pathway in GGH(3) cells. Biol. Reprod. 65, 561-567.

McCue, J. M., Quirk, C. C., Nelson, S. E., Bowen, R. A., and Clay, C. M. (1997). Expression of a murine gonadotropin-releasing hormone receptor-luciferase fusion gene in transgenic mice is diminished by immunoneutralization of gonadotropin-releasing hormone. Endocrinology 138, 3154-3160.

McGillivray, S. M., Bailey, J. S., Ramezani, R., Kirkwood, B. J., and Mellon, P. L. (2005). Mouse GnRH receptor gene expression is mediated by the LHX3 homeodomain protein. Endocrinology 146, 2180-2185.

Meldi, L., and Brickner, J. H. (2011). Compartmentalization of the nucleus. Trends Cell Biol. 21, 701-708.

Montgomery, G. W., Penty, J. M., Lord, E. A., Brooks, J., and McNeilly, A. S. (1995). The gonadotrophin-releasing hormone receptor maps to sheep chromosome 6 outside of the region of the FecB locus. Mamm. Genome 6, 436-438.

Morrison, N., Sellar, R. E., Boyd, E. Eidne, K. A., and Connor, J. M. (1994). Assignment of the gene encoding the human gonadotropinreleasing hormone receptor to $4 \mathrm{q} 13.2-13.3$ by fluorescence in situ hybridization. Hum. Genet. 93 714-715.

Mullen, R. D., Park, S., and Rhodes, S. J. (2012). A distal modular enhancer complex acts to control pituitaryand nervous system-specific expression of the LHX3 regulatory gene. Mol. Endocrinol. 26, 308-319.

Ngan, E. S., Cheng, P. K., Leung, P. C., and Chow, B. K. (1999). Steroidogenic factor-1 interacts with a gonadotrope-specific element within the first exon of the human gonadotropin-releasing hormone receptor gene to mediate gonadotrope-specific expression. Endocrinology 140, 2452-2462.

Ngan, E. S., Leung, P. C., and Chow, B. K. (2000). Identification of an upstream promoter in the human gonadotropinreleasing hormone receptor gene. Biochem. Biophys. Res. Commun. 270, 766-772.

Ngan, E. S., Leung, P. C., and Chow, B. K. (2001). Interplay of pituitary adenylate cyclase-activating polypeptide with a silencer element to regulate the upstream promoter of the human gonadotropin-releasing hormone receptor gene. Mol. Cell. Endocrinol. 176, 135-144.

Ngô, V. M., Laverrière, J. N., and Gourdji, D. (1995). CpG methylation represses the activity of the rat prolactin promoter in rat $\mathrm{GH} 3$ pituitary cell lines. Mol. Cell. Endocrinol. 108, 95-105.

Noel, S. D., and Kaiser, U. B. (2011). G protein-coupled receptors involved in GnRH regulation: molecular insights from human disease. Mol. Cell. Endocrinol. 346, 91-101.

Norwitz, E. R., Cardona, G. R., Jeong, K. H., and Chin, W. W. (1999b). Identification and characterization of the gonadotropin-releasing hormone response elements in the mouse gonadotropin-releasing hormone receptor gene. J. Biol. Chem. 274, 867-880.

Norwitz, E. R., Jeong, K. H., and Chin, W. W. (1999a). Molecular mechanisms of gonadotropin-releasing hormone receptor gene regulation. J. Soc. Gynecol. Investig. 6, 169-178.

Norwitz, E. R., Xu, S., Jeong, K. H., Bedecarrats, G. Y., Winebrenner, L. D., Chin, W. W., et al. (2002a). Activin
A augments GnRH-mediated transcriptional activation of the mouse Gnrhr. Endocrinology 143, 985-997.

Norwitz, E. R., Xu, S., Xu, J., Spiryda, L. B., Park, J. S., Jeong, K. H., et al. (2002b). Direct binding of AP-1 (Fos/Jun) proteins to a SMAD binding element facilitates both gonadotropinreleasing hormone (GnRH)- and activin-mediated transcriptional activation of the mouse GnRH receptor gene. J. Biol. Chem. 277, 3746937478.

Pincas, H., Amoyel, K., Counis, R., and Laverriere, J. N. (2001a). Proximal cis-acting elements, including steroidogenic factor 1 , mediate the efficiency of a distal enhancer in the promoter of the rat gonadotropin-releasing hormone receptor gene. Mol. Endocrinol. 15, 319-337.

Pincas, H., Laverriere, J. N., and Counis, R. (2001b). Pituitary adenylate cyclase-activating polypeptide and cyclic adenosine $3^{\prime}, 5^{\prime}$-monophosphate stimulate the promoter activity of the rat gonadotropin-releasing hormone receptor gene via a bipartite response element in gonadotropederived cells. J. Biol. Chem. 276, 23562-23571.

Pincas, H., Forrai, Z., Chauvin, S., Laverriere, J. N., and Counis, R. (1998). Multiple elements in the distal part of the $1.2 \mathrm{~kb} 5^{\prime}$ flanking region of the rat Gnrhr regulate gonadotrope-specific expression conferred by proximal domain. Mol. Cell. Endocrinol. 144, 95-108.

Pirrotta, V., and Li, H. B. (2012). A view of nuclear polycomb bodies. Curr. Opin. Genet. Dev. 22, 101-109.

Reinhart, J., Xiao, S., Arora, K. K., and Catt, K. J. (1997). Structural organization and characterization of the promoter region of the rat gonadotropin-releasing hormone receptor gene. Mol. Cell. Endocrinol. 130, 1-12.

Resuehr, D., Wildemann, U., Sikes, H., and Olcese, J. (2007). E-box regulation of gonadotropin-releasing hormone $(\mathrm{GnRH})$ receptor expression in immortalized gonadotrope cells. Mol. Cell. Endocrinol. 278, 36-43.

Roesler, W. J. (2000). What is a cAMP response unit? Mol. Cell. Endocrinol. $162,1-7$.

Sadie, H., Styger, G., and Hapgood, J. (2003). Expression of the mouse gonadotropin-releasing hormone receptor gene in alpha $\mathrm{T} 3$ 1 gonadotrope cells is stimulated by cyclic $3^{\prime}, 5^{\prime}$-adenosine monophosphate and protein kinase $A$, and is modulated by steroidogenic factor1 and Nur77. Endocrinology. 144, 1958-1971.

Schang, A. L., Bleux, C., Chenut, M. C., Ngô-Muller, V., Quérat, B., Jeanny, J. C., et al. (2012a). Identification and analysis of two novel sites of rat GnRH receptor gene promoter activity: the pineal gland and retina. Neuroendocrinology. doi: 10.1159/000337661 [Epub ahead of print].

Schang, A. L., Granger, A., Quérat, B., Bleux, C., Cohen-Tannoudji, J., and Laverrière, J. N. (2012b). GATA2-induced silencing and LIMhomeodomain protein-induced activation are mediated by a bifunctional response element in the rat $\mathrm{GnRH}$ receptor gene. Mol. Endocrinol. (in press).

Schang, A. L., Counis, R., Magre, S., Bleux, C., Granger, A., Ngô-Muller, V., et al. (2011a). Reporter transgenic mouse models highlight the dual endocrine and neural facet of GnRH receptor function. Ann. N. Y. Acad. Sci. 1220, 16-22.

Schang, A. L., Ngô-Muller, V., Bleux, C., Granger, A., Chenut, M. C., Loudes, C., etal. (2011b). GnRH receptor gene expression in the developing rat hippocampus: transcriptional regulation and potential roles in neuronal plasticity. Endocrinology 152, 568-580.

Schlosser, G. (2006). Induction and specification of cranial placodes. Dev. Biol. 294, 303-351.

Schuettengruber, B., Chourrout, D., Vervoort, M., Leblanc, B., and Cavalli, G. (2007). Genome regulation by polycomb and trithorax proteins. Cell 128, 735-745.

Scully, K. M., and Rosenfeld, M. G. (2002). Pituitary development: regulatory codes in mammalian organogenesis. Science 295, 2231-2235.

Shima, Y., Miyabayashi, K., Baba, T., Otake, H., Oka, S., Zubair, M., et al. (2012). Identification of an enhancer in the Ad4BP/SF-1 gene specific for fetal Leydig cells. Endocrinology 153, 417-425.

Silveira, L. F., Stewart, P. M., Thomas, M., Clark, D. A., Bouloux, P. M., and MacColl, G. S. (2002). Novel homozygous splice acceptor site GnRHR (GnRHR) mutation: human GnRHR "knockout." J. Clin. Endocrinol. Metab. 87, 2973-2977.

Simon, J. A., and Kingston, R. E. (2009). Mechanisms of polycomb gene silencing: knowns and unknowns. Nat. Rev. Mol. Cell Biol. 10, 697-708.

Sosnowski, R., Mellon, P. L., and Lawson, M. A. (2000). Activation of 
translation in pituitary gonadotrope cells by gonadotropin-releasing hormone. Mol. Endocrinol. 14, 18111819.

Spector, D. L., and Lamond, A. I. (2011). Nuclear speckles. Cold Spring Harb. Perspect. Biol. 3, a000646.

Stanislaus, D., Arora, V., Awara, W. M., and Conn, P. M. (1996). Biphasic action of cyclic adenosine $3^{\prime}, 5^{\prime}$ monophosphate in gonadotropinreleasing hormone $(\mathrm{GnRH})$ analog-stimulated hormone release from GH3 cells stably transfected with GnRHR complementary deoxyribonucleic acid. Endocrinology 137, 1025-1031.

Stanislaus, D., Janovick, J. A., Jennes, L., Kaiser, U. B., Chin, W. W., and Conn, P. M. (1994). Functional and morphological characterization of four cell lines derived from GH3 cells stably transfected with gonadotropinreleasing hormone receptor complementary deoxyribonucleic acid. Endocrinology 135, 2220-2227.

Stewart, A. J., Katz, A. A., Millar, R. P., and Morgan, K. (2009). Retention and silencing of prepro-GnRHII and type II GnRH receptor genes in mammals. Neuroendocrinology 90 , 416-432.

Stojilkovic, S. S., Reinhart, J., and Catt, K. J. (1994). Gonadotropin-releasing hormone receptors: structure and signal transduction pathways. Endocr. Rev. 15, 462-499.

Stopa, M., Anhuf, D., Terstegen, L., Gatsios, P., Gressner, A. M., and Dooley, S. (2000). Participation of Smad2, Smad3, and Smad4 in transforming growth factor beta (TGF-beta)induced activation of Smad7. The
TGF-beta response element of the promoter requires functional Smad binding element and E-box sequences for transcriptional regulation. J. Biol. Chem. 275, 29308-29317.

Thomas, P., Mellon, P. L., Turgeon, J., and Waring, D. W. (1996). The L beta T2 clonal gonadotrope: a model for single cell studies of endocrine cell secretion. Endocrinology 137, 29792989.

Turgeon, J. L., Kimura, Y., Waring, D. W., and Mellon, P. L. (1996). Steroid and pulsatile gonadotropin-releasing hormone $(\mathrm{GnRH})$ regulation of luteinizing hormone and GnRH receptor in a novel gonadotrope cell line. Mol. Endocrinol. 10, 439-450.

Turzillo, A. M., DiGregorio, G. B. and Nett, T. M. (1995). Messenger ribonucleic acid for gonadotropinreleasing hormone receptor and numbers of gonadotropin releasing hormone receptors in ovariectomized ewes after hypothalamic pituitary disconnection and treatment with estradiol. J. Anim. Sci. 73, 1784-1788.

Vazquez-Martinez, R., Shorte, S. L., Boockfor, F. R., and Frawley, L. S. (2001). Synchronized exocytotic bursts from gonadotropin-releasing hormone-expressing cells: dual control by intrinsic cellular pulsatility and gap junctional communication. Endocrinology 142, 2095-2101.

Walton, K. L., Makanji, Y., and Harrison, C. A. (2012). New insights into the mechanisms of activin action and inhibition. Mol. Cell. Endocrinol. 359, 2-12.

Weiss, J., Crowley, W. F. Jr, Halvorson, L. M., and Jameson, J. L.
(1993). Perifusion of rat pituitary cells with gonadotropin-releasing hormone, activin, and inhibin reveals distinct effects on gonadotropin gene expression and secretion. Endocrinology 132, 2307-2311.

Wen, S., Schwarz, J. R., Niculescu, D., Dinu, C., Bauer, C. K., Hirdes, W., etal. (2008). Functional characterization of genetically labeled gonadotropes. Endocrinology 149, 2701-2711.

White, B. R., Duval, D. L., Mulvaney, J. M., Roberson, M. S., and Clay, C. M. (1999). Homologous regulation of the gonadotropin-releasing hormone receptor gene is partially mediated by protein kinase $\mathrm{C}$ activation of an activator protein-1 element. Mol. Endocrinol. 13, 566-577.

Wilson, M. D., Barbosa-Morais, N. L., Schmidt, D., Conboy, C. M., Vanes, L., Tybulewicz, V. L., et al. (2008). Species-specific transcription in mice carrying human chromosome 21. Science 322, 434-438.

Windle, J. J., Weiner R. I., and Mellon P. L. (1990). Cell lines of the pituitary gonadotrope lineage derived by targeted oncogenesis in transgenic mice. Mol. Endocrinol. 4, 597-603.

Yang, L., Lin, C., Liu, W., Zhang, J., Ohgi, K. A., Grinstein, J. D., et al. (2011). ncRNA- and Pc2 methylation-dependent gene relocation between nuclear structures mediates gene activation programs. Cell 147, 773-788.

Yeung, C. M., An, B. S., Cheng, C. K., Chow, B. K., and Leung, P. C. (2005). Expression and transcriptional regulation of the GnRH receptor gene in human neuronal cells. Mol. Hum. Reprod. 11, 837-842.

Zhao, L., Bakke, M., and Parker, K. L. (2001). Pituitary-specific knockout of steroidogenic factor 1. Mol. Cell. Endocrinol. 185, 27-32.

Conflict of Interest Statement: The authors declare that the research was conducted in the absence of any commercial or financial relationships that could be construed as a potential conflict of interest.

Received: 13 September 2012; paper pending published: 12 November 2012; accepted: 28 November 2012; published online: 13 December 2012.

Citation: Schang A-L, Quérat B, Simon $V$, Garrel G, Bleux C, Counis $R$, Cohen-Tannoudji $J$ and Laverrière J$N$ (2012) Mechanisms underlying the tissue-specific and regulated activity of the Gnrhr promoter in mammals. Front. Endocrin. 3:162. doi: 10.3389/fendo. 2012.00162

This article was submitted to Frontiers in Neuroendocrine Science, a specialty of Frontiers in Endocrinology.

Copyright (C) 2012 Schang, Quérat, Simon, Garrel, Bleux, Counis, CohenTannoudji and Laverrière. This is an open-access article distributed under the terms of the Creative Commons Attribution License, which permits use, distribution and reproduction in other forums, provided the original authors and source are credited and subject to any copyright notices concerning any thirdparty graphics etc. 